\title{
Hydrochemistry, weathering and weathering rates on Madeira island
}

\author{
Cornelis H. Van der Weijden ${ }^{\mathrm{a}, *}$, Fernando A.L. Pacheco ${ }^{\mathrm{b}, 1}$ \\ ${ }^{\mathrm{a}}$ Department of Geochemistry, Faculty of Earth Sciences, Utrecht University, Budapestlaan 4, P.O. Box 80.021, 3508 TA Utrecht, \\ The Netherlands \\ ${ }^{\mathrm{b}}$ Department of Geology, Tràs-os-Montes e Alto Douro University, 5000 Vila Real, Portugal
}

Received 15 July 2002; accepted 1 July 2003

\begin{abstract}
Madeira island consists of Miocene to Pleistocene lavas and pyroclasts. Major rock types are alkali-basalts, basanites and hawaiites; principal soil types are leptosols, andosols and cambisols. Our main objective was to link the chemistry of ground waters to weathering reactions and rates. We collected 40 shallow groundwater samples, remote from human activities. With a few exceptions, the ranges of electrical conductivities were $29-176 \mu \mathrm{S} / \mathrm{cm}$ and of $\mathrm{pH} 5.8-8.5$. The calculated $P_{\mathrm{CO}_{2}}$ was generally higher than the atmospheric value. The contribution of sea salt to the water chemistry was $30 \pm 9 \%$. Corrected for sea salt, the cation concentrations (in meq/l) decrease in the order $\mathrm{Ca}^{2+} \approx \mathrm{Mg}^{2+}>\mathrm{Na}^{+}>>>\mathrm{K}^{+}$. The concentrations of $\mathrm{SO}_{4}^{2-}$ and $\mathrm{NO}_{3}^{-}$are very low. We calculated that the total annual chemical denudation rate in the studied area amounts to $37 \pm 12 \mathrm{~g} / \mathrm{m}^{2}$, consuming $0.86 \pm 0.38 \mathrm{~mol} \mathrm{CO} / \mathrm{m}^{2}$. To achieve our main objective, a set of mole balance equations$(A X=B)$-was used, where $A$ is a composite matrix of coefficients, including ratios between stoichiometric coefficients as determined by the weathering reactions and coefficients accounting for unconstrained contributions, $B$ is the vector with a water composition, and $X$ is the set of mole fractions of dissolved primary minerals plus the residual concentrations of the unconstrained contributions. Olivine $(\mathrm{Ol})$, pyroxene $(\mathrm{Py})$ and plagioclase $(\mathrm{Pl})$ were considered to be the major primary minerals, and smectite, vermiculite, halloysite, allophane, gibbsite and hematite the secondary minerals in the weathering reactions. Using iterative procedures, whereby mixtures of secondary products as well as the composition of plagioclase are allowed to change, we selected one best-fit set of weathering reactions for each spring by checking all possible solutions of the mole balances against predefined boundary conditions. At odds with Goldich (1938) sequence, our model results indicate-for most best-fit sets-a weathering rate sequence of $\mathrm{Pl}>\mathrm{Ol}>\mathrm{Py}$, but such reverse order is not unique. On average, the annual weathering rates (in $\mathrm{mol} /($ ha y vol\% mineral)) are $44 \pm 19(\mathrm{Pl}), 29 \pm 14(\mathrm{Ol})$ and $22 \pm 13(\mathrm{Py})$.

(c) 2003 Elsevier B.V. All rights reserved.
\end{abstract}

Keywords: Madeira; Basalt; Chemical weathering; Hydrochemistry; Mass-balance modelling

\footnotetext{
* Corresponding author. Address: Rijksuniversiteit Utrecht, Afdeling Geochemie, Instituut voor Aardwetenschappen, Postbus 80.021, Utrecht 3508 TA, Netherlands. Fax: +31-30-253-5302.

E-mail addresses: chvdw@geo.uu.nl (C.H. Van der Weijden), fpacheco@utad.pt (F.A.L. Pacheco).

${ }^{1}$ Fax: + 351-259-350-480.
}

\section{Introduction}

Basalts may only cover a small part of the subaerial surface of the earth, but their relatively high weatherability renders them an important sink in the $\mathrm{CO}_{2}$ 
cycle. For that reason, weathering of basalt is an attractive research subject. An exhaustive overview of numerous studies conducted on this topic can be found in Gíslason et al. (1996). A few papers, relevant for our own study, will be referred to in this paper. A classical paper is the one by Goldich (1938), who proposed the well-known sequence of weathering rates of rock-forming minerals. Monographs on weathering are those by Loughnan (1969), Sverdrup (1990), and Bland and Rolls (1998).

Weathering can be studied on the basis of the development of the mineralogy and(or) chemistry from fresh rock to weathering rinds and profiles. Examples for basalt weathering have been presented by Craig and Loughnan (1964), Chesworth et al. (1981), Benson and Teague (1982), Colman (1982), Eggleton et al. (1987), Noack et al. (1990), and Nesbitt and Wilson (1992). Some studies have zoomed in on the transformation of primary into secondary phases during various stages of weathering on a microscopic scale. Examples can be found in Colman (1982), Eggleton and Smith (1983), Smith et al. (1987), Banfield et al. (1990), Wasklewicz (1994), and Berner and Cochran (1998). Another approach is to use the chemistry of water to determine the mobility and fluxes of elements in drainage of basaltic terrain, based on which denudation rates and $\mathrm{CO}_{2}$ consumption can be estimated. Some examples are the studies by Li (1988) on the Hawaiian islands, by Gíslason and co-workers (1987, 1993, 1994, 1996) and Stefánsson and Gíslason (2001) on Iceland, and by Louvat and Allègre (1997) on Réunion.

A third angle is to link the mineralogy and chemistry of fresh rock and its weathering products by the solutes acquired in the weathering profile as a result of water-rock interaction. A reverse weathering reaction can represent this:

$$
\text { weathered material }+ \text { solutes } \rightarrow \text { fresh rock }
$$$$
+\mathrm{CO}_{2}+\mathrm{H}_{2} \mathrm{O} \text {. }
$$

This approach was introduced by Garrels and Mackenzie (1967) and since then has been given prominence to in many geochemical textbooks. More sophisticated models also take into account the uptake or release of vegetation (Taylor and Velbel, 1991; Pacheco et al., 1999) and ion-exchange processes (Sverdrup, 1990). This extended model is nicely portrayed by Drever (1997). The models become even more complicated when also input from atmospheric pollution and agricultural, industrial and domestic sources have to be considered (e.g. Pacheco et al., 1999; Pacheco and Van der Weijden, 2002). This is the reason why pristine areas are to be preferred over populated areas for studies of natural weathering.

With the focus on basalt, volcanic islands (Hawaii, Iceland, Réunion) have been popular places to investigate weathering. In our paper we present a weathering study on another volcanic islandMadeira. We collected water samples from springs and brooklets in areas remote from anthropogenic influences and collected data about the mineralogy and chemistry of the fresh rocks and soils. We used a weathering model in which the ratio of dissolved silica to bicarbonate is a key parameter (cf. Garrels, 1967; Pacheco and Van der Weijden, 1996). With this model it is possible to estimate the contributions of the various rock-forming minerals to the water chemistry. The model results that fitted the boundary conditions best were accepted as representative of the actual weathering processes.

\section{Area description}

Madeira island is located in the Atlantic Ocean, approximately $750 \mathrm{~km}$ off $\mathrm{W}$. Morocco; latitude and longitude spans are $32^{\circ} 30^{\prime}-33^{\circ} 30^{\prime} \mathrm{N}$ and $16^{\circ} 30^{\prime}-$ $17^{\circ} 30^{\prime} \mathrm{W}$. The island has an area of $737 \mathrm{~km}^{2}$ with maximum altitudes around $1860 \mathrm{~m}$ (eastern side: Pico Ruivo de Santana and Pico do Arieiro) or 14001500 m (western or Paúl da Serra side (Fig. 1).

\subsection{Climate}

The Madeira relief is orthogonal to the dominantly northern wind direction. This forces humid air masses to rise and cool, a process which, apart from orographic rainfall $(P)$, frequently generates summer clouds at altitudes from about 500-1200 m (Ferreira, 1988; Madeira et al., 1994). Prada (2000) observed that the altitudes frequently exposed to fog stretch from some $600-800 \mathrm{~m}$ to $1600 \mathrm{~m}$. Rainfall increases with altitude $(H)$ and the relation between $H$ (in $\mathrm{m}$ ) and $P$ (in $\mathrm{mm} / \mathrm{y}$ ) may be described by the following 


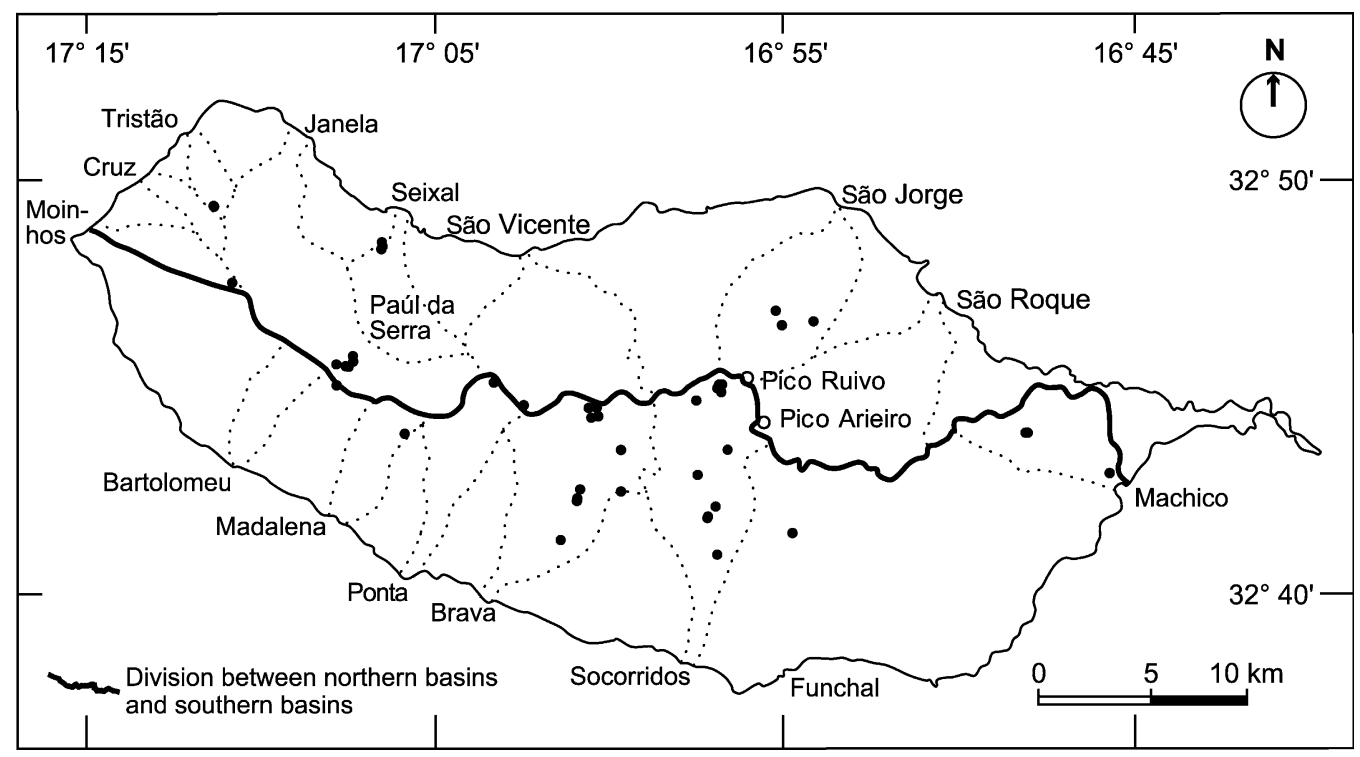

Fig. 1. Major hydrographical basins of the Madeira island. The thick line divides the basins into northern (more wet and cold) and southern (more dry and warm) basins. The bullets mark spring sites.

equations (Loureiro, 1984):

Northern Sector : $P=1262.3+1.19 \times H\left(R^{2}=0.90\right)$

Southern Sector : $P=692.5+1.53 \times H\left(R^{2}=0.95\right)$

These equations have been derived from long-term records (usually spanning a 30 years-long period) of precipitation data collected at 30 meteorological stations, 19 of which are located in the southern area and the other 11 in the northern area. They were recast into polynomial functions that suggest the dominance of slow increments in $P$ for $H<500 \mathrm{~m}$, fast increments for $500 \mathrm{~m}<H<1400 \mathrm{~m}$ and plateaus for $H>1400 \mathrm{~m}$ (Prada, 2000). In either case the equations do not encompass the contributions of fog drip and mist precipitation (Silva, 1988), so they underestimate the total flux of precipitation. For example, in a study lasting for two consecutive years and using standard fog collectors, Prada and Silva (2001) reported an occult precipitation of $5000 \mathrm{~mm} / \mathrm{y}$ in a site at $1560 \mathrm{~m}$ of altitude (Bica da Cana, eastern Paúl da Serra; Fig. 1) a value that is 1.85 times higher than the corresponding $P$, that in another site at $1183 \mathrm{~m}$ the daily productions are $70 \%$ lower, and that in vegetated areas the ratios between fog drip and $P$ tend to be the highest. The unaccounted for contributions may partly be derived from cyclic evapotranspiration upon insolation and condensation upon cooling. This is supported by the seasonal distribution of the fog drip, for which the highest values were measured from April to September.

The average annual temperature depends on altitude, with values of $17^{\circ} \mathrm{C}$ at the southern and $19{ }^{\circ} \mathrm{C}$ at the northern coast, decreasing to $9{ }^{\circ} \mathrm{C}$ in the highlands.

\subsection{Land use}

The island is densely populated-some 300,000 inhabitants plus many tourists. Most people live and work in the southern part of the island, dominantly in the coastal areas. The name Madeira refers to the lush vegetation covering the island before its discovery in 1450. Since then, large-scale tree cutting has only left original vegetation in the misty zone $(>500 \mathrm{~m})$, more extensively so in the northern sector. Overgrazing has strongly degraded the vegetation in the highland. Agriculture is an important economic activity, but chiefly occupies areas at altitudes $<600 \mathrm{~m}$ (Madeira et al., 1994). In large areas, the rugged topography restricts land use by agriculture; but, where possible 


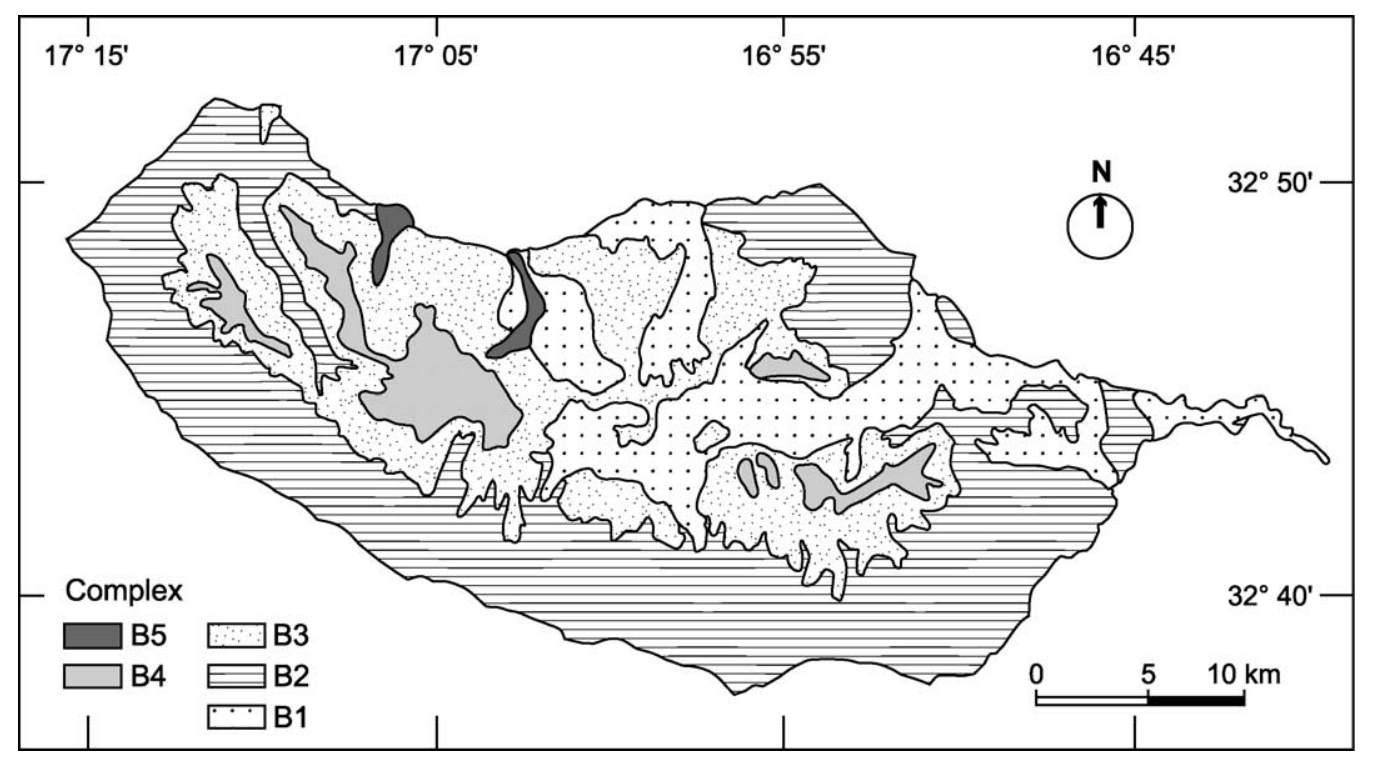

Fig. 2. Geology of Madeira Island; adopted from Mata (1996) after original map by Zbyszewski et al. (1975).

and profitable, terrace cultivation has overcome topographic barriers. To secure water supply for agriculture, an ingenious system of aqueducts, called 'levadas' and measuring more than $2000 \mathrm{~km}$ in length, was built. Levadas divert water, otherwise discharged by streams and rivers, from its sources in the highland directly to the distribution centres for irrigation systems. Although nowadays some of these conduits are obsolete, others are still operative and also used for domestic water supply.

\subsection{Geology, petrology, mineralogy}

Fig. 2 (after Zbyszewski et al., 1975) shows the geology of Madeira. The island was born in the Miocene from explosive submarine eruptions represented by coarse basaltic pyroclasts (B1 complex). After a long pause in the volcanic activity, an extensive and heterogeneous complex was formed where explosive (basaltic pyroclasts) and effusive (basaltic flows) materials intermix (B2 complex). Following another interruption, a new but less extensive basaltic complex was generated (B3 complex), where basaltic flows clearly dominate over pyroclastic materials. Subsequently, the B3 complex was overlain by thick and compact basaltic flows attributed to fissural volcanism (B4 complex), and recently the last eruptions filled already existing valleys of the Northwest sector of the island (B5 complex).

The petrology of the Madeira rocks was compiled from Mata (1996). Geological complexes B1-B5 are mainly composed of basalts plus basanites, with minor contributions of hawaiites, mugearites and picrobasalts; average mineralogical compositions of basalts plus basanites are shown in Table 1. Electron microprobe analyses have been conducted by Mata (1996) on olivine (325 analyses), pyroxene (162) and spinel (99) crystals selected from a total of 65 rock samples. Structural formulas were derived from the average chemical compositions (Table 1). Olivines are strongly zoned, with compositions going from $\mathrm{Fa}=62.5 \%$ at the border of the crystals to $\mathrm{Fa}=12 \%$ at their cores.

\subsection{Hydrology}

The major hydrographic basins on Madeira island are shown in Fig. 1. In four of these basins (São Vicente, Socorridos, Brava e Machico), a total of 11 precipitation records were available from meteorological stations, and water balances have been calculated (Novo et al., 1994) from these data using the BALSEQ method of Ferreira and Rodrigues (1987). The results of the water balances of the basins were then used as proxies of the balances at the scale 
Table 1

Compositions and average abundances (in vol.\%) of major rock-forming minerals in the geological complexes B1-B5 (Fig. 2); $\mathrm{x}=$ anorthite fraction, $\mathrm{n}=$ number of rock samples from which the abundances were calculated

\begin{tabular}{|c|c|c|c|c|c|c|}
\hline \multirow{2}{*}{$\begin{array}{l}\text { Chemical composition in mineral-forming } \\
\text { oxides (structural } \mathrm{H}_{2} \mathrm{O} \text { omitted) }\end{array}$} & Geological complex $\rightarrow$ & $\mathrm{B} 1$ & $\mathrm{~B} 2$ & B3 & B4 & B5 \\
\hline & $\begin{array}{l}n \\
x \text { (range) }\end{array}$ & $\begin{array}{l}22 \\
0.4-0.8\end{array}$ & $\begin{array}{l}19 \\
0.45-0.7\end{array}$ & $\begin{array}{l}7 \\
0.55-0.8\end{array}$ & $\begin{array}{l}10 \\
0.55-0.75\end{array}$ & $\begin{array}{l}7 \\
0.6-0.85\end{array}$ \\
\hline $\begin{array}{l}0.5(1-x) \mathrm{Na}_{2} \mathrm{O} \cdot x \mathrm{CaO} \cdot 0.5 \\
(1+x) \mathrm{Al}_{2} \mathrm{O}_{3} \cdot(3-x) \mathrm{SiO}_{2}\end{array}$ & Plagioclase & 48 & 46 & 45 & 46 & 40 \\
\hline $\mathrm{CaO} \cdot 0.7 \mathrm{MgO} \cdot 0.3 \mathrm{FeO} \cdot 0.1 \mathrm{Al}_{2} \mathrm{O}_{3} \cdot 1.8 \mathrm{SiO}_{2}$ & Pyroxene & 23 & 22 & 23 & 23 & 21 \\
\hline $1.5 \mathrm{MgO} \cdot 0.5 \mathrm{FeO} \cdot \mathrm{SiO}_{2}$ & Olivine (average) & 22 & 26 & 24 & 25 & 35 \\
\hline $0.5 \mathrm{~K}_{2} \mathrm{O} \cdot 0.5 \mathrm{Al}_{2} \mathrm{O}_{3} \cdot 3 \mathrm{SiO}_{2}$ & K-feldspar & 4.4 & 4.4 & 6.5 & 3.1 & 1.6 \\
\hline $5 \mathrm{CaO} \cdot 3 \mathrm{PO}_{4}$ & Apatite & 1.7 & 1.5 & 1.1 & 1.7 & 2 \\
\hline $\begin{array}{l}4.4 \mathrm{TiO}_{2} \cdot 0.6 \mathrm{Al}_{2} \mathrm{O}_{3} \cdot 0.2 \mathrm{Cr}_{2} \mathrm{O}_{3} \cdot 2.8 \mathrm{Fe}_{2} \mathrm{O}_{3} . \\
10.7 \mathrm{FeO} \cdot 0.1 \mathrm{MnO} \cdot 1.6 \mathrm{MgO}\end{array}$ & Spinel & 0.8 & 0.6 & 0.7 & 0.6 & 0.2 \\
\hline
\end{tabular}

of the catchments of the springs; the relation between the hydrology of the basins and the springs was established as follows:

(1) The average values of $P$ (measured), $Q_{\mathrm{s}}$ and $R$ (computed by the BALSEQ method) for the basins were fitted to the following power and logarithmic equations:

$Q_{\mathrm{s}}=8 \times 10^{-5} \times P^{2.0235} \quad R^{2}=0.98$

$R=922.7 \times \ln (P)-6114.6 \quad R^{2}=0.96$

where $Q_{\mathrm{s}}$ is the overland flow and $R$ the recharge.

The graphical representations of the data points and of the fits are shown in Fig. 3. Although empirical, Eqs. (2a,b) encompass the physical process of aquifer saturation in response to rainfall increment, whereby the rate at which the recharge is growing decreases progressively and the rate at which surface flow is growing increases proportionally.

(2) introducing in Eqs. (2a,b) the $P$ values of each spring, as computed by Eqs. (1a,b), the corresponding $Q_{\text {s }}$ and $R$ values were calculated.

Recharge is a key parameter for the assessment of fluxes and weathering rates. However, the values of $R$, as determined by Eq. (2b), underestimate the true recharges if fog drip is an important source. As measured by Prada (2000) and Prada and Silva (2001), overcast at altitudes from 600-800 to $1600 \mathrm{~m}$ produces an abundant fog drip. Most of the spring sites in the present study (75\%) are located at those altitudes, meaning that a complementary method such as the balance of chlorides is needed to estimate recharge. This is a reliable method of recharge estimation when chloride in water is dominantly from atmospheric origin; in brief, it involves two steps (Custodio and Llamas, 1983):

(1) If $P \mathrm{~mm} / \mathrm{y}$ rain, with $\left[\mathrm{Cl}^{-}\right]_{\mathrm{r}} \mathrm{mol} / \mathrm{l}$, falls on a certain area, of which $Q_{\mathrm{s}} \mathrm{mm} / \mathrm{y}$ are converted into direct discharge and $E \mathrm{~mm} / \mathrm{y}$ are evapotranspired, then the recharge $(R)$ will be given by

$R=P-Q_{\mathrm{s}}-E$

(2) If $\left[\mathrm{Cl}^{-}\right]_{\mathrm{s}}$ is the chloride content in infiltrated water (sampled at a spring site), then the balance of the chloride is represented by

$\left[\mathrm{Cl}^{-}\right]_{\mathrm{s}} \times R=\left(P-Q_{\mathrm{s}}\right) \times\left[\mathrm{Cl}^{-}\right]_{\mathrm{r}}$

or

$R=\left(P-Q_{\mathrm{s}}\right) \times \frac{\left[\mathrm{Cl}^{-}\right]_{\mathrm{r}}}{\left[\mathrm{Cl}^{-}\right]_{\mathrm{S}}}$

When a mixture of precipitation plus fog drip contributes to recharge, Eq. (2e) has to be recast into

$R=\left(P+F-Q_{\mathrm{s}}\right) \times \frac{\left[\mathrm{Cl}^{-}\right]_{\mathrm{rf}}}{\left[\mathrm{Cl}^{-}\right]_{\mathrm{s}}}$

where $F$ is the amount of fog drip $(\mathrm{mm} / \mathrm{y})$ and $\left[\mathrm{Cl}^{-}\right]_{\mathrm{rf}}$ is the chloride concentration of the mixed water, which is given by:

$\left[\mathrm{Cl}^{-}\right]_{\mathrm{rf}}=\frac{\left[\mathrm{Cl}^{-}\right]_{r}+\alpha\left[\mathrm{Cl}^{-}\right]_{f}}{1+\alpha}$

In Eq. $(2 \mathrm{~g}),\left[\mathrm{Cl}^{-}\right]_{\mathrm{f}}$ is the chloride content of fogcondensed water and $\alpha=F / P$. 


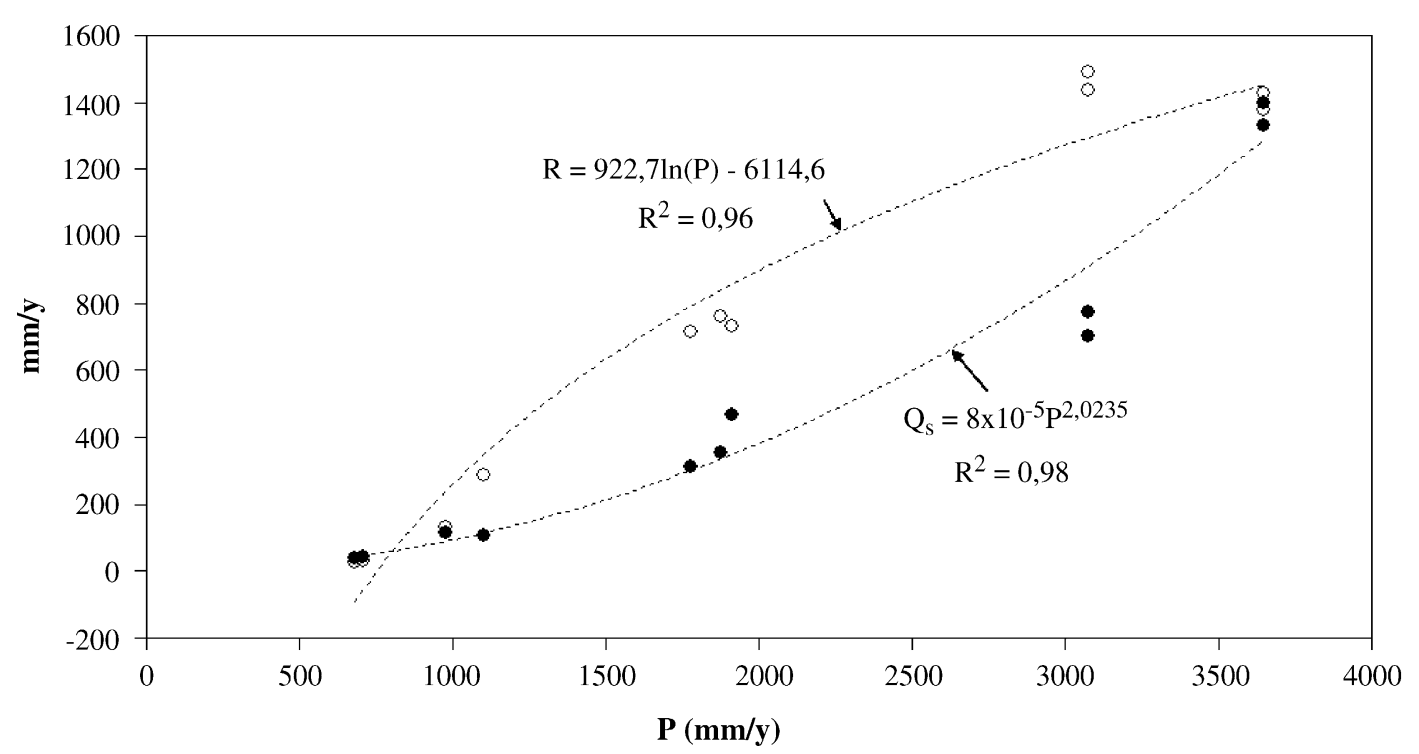

Fig. 3. Relation between surface runoff $\left(Q_{\mathrm{s}}\right)$ and annual precipitation $(P)$, as well as between recharge $(R)$ and $P$ on Madeira island. Data used in the graph are from Ribeira de São Vicente, Ribeira dos Socorridos, Ribeira Brava and Ribeira de Machico (Novo et al., 1994). These basins cover the area in which most of our water samples were collected (cf. Fig. 1).

Apart from the $P$ and $Q_{\mathrm{s}}$ values, which are derived by Eqs. $(1 \mathrm{a}, \mathrm{b})$ from the altitudes of the springs (Appendix), calculation of the recharge by Eq. (2f) requires knowledge of $\alpha,\left[\mathrm{Cl}^{-}\right]_{\mathrm{f}},\left[\mathrm{Cl}^{-}\right]_{\mathrm{r}}$ and $\left[\mathrm{Cl}^{-}\right]_{\mathrm{s}}$. The $\left[\mathrm{Cl}^{-}\right]_{\mathrm{s}}$ values are listed in Appendix, Nascimento (1990) reported that $\left[\mathrm{Cl}^{-}\right]_{\mathrm{r}}=0.183 \pm 0.037 \mathrm{mM}$ $(n=7)$, but an average $\left[\mathrm{Cl}^{-}\right]_{\mathrm{f}}$ value is not available. For the Bica da Cana site (eastern Paúl da Serra; Fig. 1) $\alpha=1.85$ (Prada and Silva, 2001), which can be used as a reference value for spring sites located at an altitude around $1600 \mathrm{~m}$.

Considering the information at our disposal, application of Eq. (2f) is beyond reach unless prior guesses of a satisfactory $\left[\mathrm{Cl}^{-}\right]_{\mathrm{f}}$ and of acceptable $\left[\mathrm{Cl}^{-}\right]_{\mathrm{rf}}$ and $\alpha$ values for each spring site are made. The estimation of $\left[\mathrm{Cl}^{-}\right]_{\mathrm{rf}}$ relies on the concept of an evaporation factor $(\beta=1-\gamma)$-the portion of the water available for potential recharge but annually consumed by evapotranspiration-in which $\gamma$ is given by:

$\gamma=\frac{\left[\mathrm{Cl}^{-}\right]_{\mathrm{r}}}{\left[\mathrm{Cl}^{-}\right]_{\mathrm{sr}}}=\frac{\left[\mathrm{Cl}^{-}\right]_{\mathrm{rf}}}{\left[\mathrm{Cl}^{-}\right]_{\mathrm{srf}}}$

and where the subscripts "sr" and "srf" mean resulting in springs from evaporation of rainwater or from evaporation of a mixture containing fog drip plus rainwater, respectively. The $\gamma$ value for each spring site may directly be determined by Eq. (2e), providing that the $R$ and $Q_{\mathrm{s}}$ parameters have already been determined by the BALSEQ method. Then the $\left[\mathrm{Cl}^{-}\right]_{\mathrm{rf}}$ is deduced from the $\left[\mathrm{Cl}^{-}\right]_{\text {srf }}$ in Appendix (chloride concentrations in the samples) in combination with Eq. (2h):

$\left[\mathrm{Cl}^{-}\right]_{\mathrm{rf}}=\gamma \times\left[\mathrm{Cl}^{-}\right]_{\mathrm{srf}}$

To estimate an acceptable value for $\left[\mathrm{Cl}^{-}\right]_{\mathrm{f}} \mathrm{Eq}$. $(2 \mathrm{~g})$ is applied for spring site nr. 141, located at an altitude of $1570 \mathrm{~m}$, similar to that of Bica da Cana. With $\alpha=1.85$ (measured at Bica da Cana) and $\left[\mathrm{Cl}^{-}\right]_{\mathrm{rf}}$ calculated from the corresponding $\left[\mathrm{Cl}^{-}\right]_{\mathrm{srf}}$, the value obtained for $\left[\mathrm{Cl}^{-}\right]_{\mathrm{f}}$ was $0.04 \mathrm{mM}$. Next, values of $\alpha$ for the other samples are obtained assuming that $\left[\mathrm{Cl}^{-}\right]_{\mathrm{f}}=0.04 \mathrm{mM}$ and using the measured $\left[\mathrm{Cl}^{-}\right]_{\mathrm{r}}$ (Nascimento, 1990) and the estimated $\left[\mathrm{Cl}^{-}\right]_{\mathrm{rf}}$ (Eq. (2i)). Finally, the recharge for each spring site was estimated (Eq. (2f)) using $F=\alpha P$ and assuming $Q_{\mathrm{s}}=8 \times 10^{-5}(P+F)^{2.0235}$ (Eq. (2a))

The recharges in the catchment of each spring, as determined by the water-balance method (no fog drip included) and by the chloride-balance method (fog drip included), are illustrated in the line-type plot of 


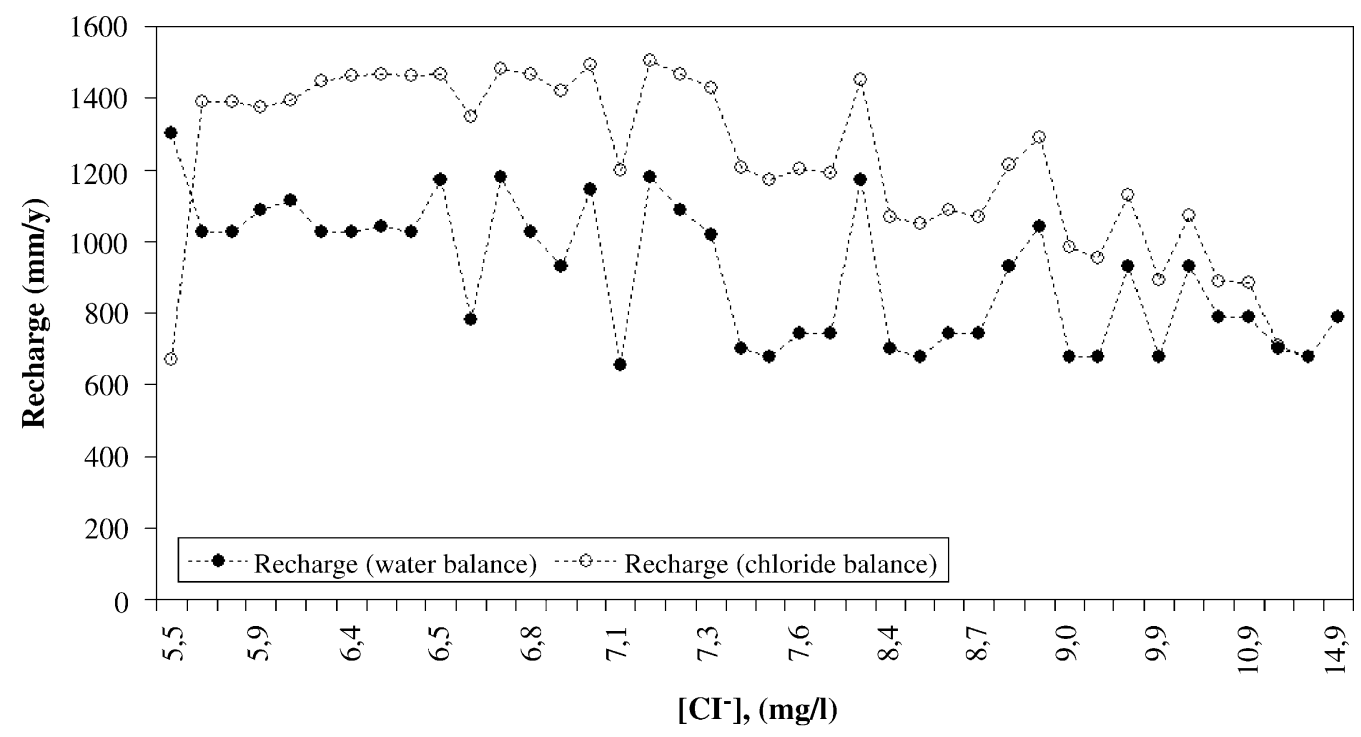

Fig. 4. Annual recharge rates $(R)$ in the catchment of the springs versus the chloride concentrations (sorted in ascending order) in the water samples. Open symbols represent $R$ 's estimated by the water-balance method, solid symbols the $R$ 's estimated by the chloride-balance method (explanation in text). The difference between the $R$ values represented by open and solid symbols is considered to be an effect of fog drip on the annual recharge.

$R$ vs. sorted- $\left[\mathrm{Cl}^{-}\right]_{\mathrm{s}}$ of Fig. 4 . The water-balance-based recharges are given by $R=909 \pm 191 \mathrm{~mm} / \mathrm{y}$ whereas the chloride-balance-based recharges are given by $R=1221 \pm 243 \mathrm{~mm} / \mathrm{y}$; thus, the extra recharge provided by fog drip is on average around 34\% of the water-balance-based recharges, a value that is similar to the extra recharge in the Paúl da Serra (26\%) as suggested by Prada (2000). As would be expected, the differences between recharge estimations are higher when the chloride concentration in spring water is low because usually low chloride concentrations show up when sites are located at high altitudes where fog drip contributes significantly to recharge. For two of the spring sites (nrs. 126 and 147) the calculated $\alpha$ 's resulted in negative values. It should be noted however that these springs are located at low altitudes $(\leq 600 \mathrm{~m})$, the places where fog drip may not be important as a source of recharge, and therefore their $\alpha$ 's were renumbered as $\alpha=0$. The anomalously low recharge of spring nr. $141(669 \mathrm{~mm} /$ y) hinges on the fact that the empirical relationship between $P$ and $Q_{\text {s }}$ relies on a $P+F$ range of $0-3650 \mathrm{~mm} / \mathrm{y}$ (Fig. 3) and that spring far exceeds this value $(P+F=8820 \mathrm{~mm} / \mathrm{y})$. Taking into account the value of recharge obtained for this site with the water balance method (around $1300 \mathrm{~mm} / \mathrm{y}$ ) and the estimated $34 \%$ of extra recharge provided on average by fog drip, the actual recharge for spring $\mathrm{nr}$. 141 should instead be around $1740 \mathrm{~mm} / \mathrm{y}$.

As a final step in the hydrological characterization of the study area we estimated the recharge taking place in the different geological complexes, using the medians of the calculated recharge values of the springs in each of the complexes (see Appendix). The results (in $\mathrm{mm} / \mathrm{y}$ ) are: $R_{\mathrm{B} 1}=1388, R_{\mathrm{B} 2}=1243$, $R_{\mathrm{B} 3}=1187$ and $R_{\mathrm{B} 4}=1740$ (only one sample); no spring has been mapped in the B5 complex. Variations in these $R$ values are mostly caused by variations in the rainfall around the sampling sites.

The hydraulic behaviour of geological units depends on whether they are composed mainly of pyroclastic materials or basaltic flows. Genetically, ejected materials have high total porosity (up to 60\%) but a low (coarse grained pyroclasts) to very low (fine grained pyroclasts) effective porosity and permeability. In contrast, fresh basaltic layers are permeable because of their genetic voids: cooling fractures, holes left from gas release and channels opened by circulation of lava across previously formed layers. In both cases, the capacity of geological units to transmit water decreases as the rock gets older due to progressive compaction 
(Novo et al., 1994). On the basis of these observations, and recalling that complex B1 is made mostly of pyroclasts, that $\mathrm{B} 2$ is a $1: 1$ mixture of pyroclasts and basaltic flows and that B3, B4 and B5 are formed essentially by basaltic layers, we make the assumption that permeability of the Madeira geological units obeys the sequence B5 $>$ B $4>$ B3 $>$ B2 $>$ B1. This is in fair agreement with the sequence of the median values of electrical conductivities (in $\mu \mathrm{S} / \mathrm{cm}$; see Appendix): B1 (102) > B2 (76) $\approx$ B3 $(91)>$ B4 (29). For rocks of identical composition, this may correspond to a sequence of residence times.

\subsection{Pedology}

Madeira island is covered mostly by umbric andosols and mollic/umbric leptosols, the latter types occurring in isolated areas identified by Ricardo et al. (1992) as rocky or scarped land (Fig. 5). The clay fraction $(<2 \mathrm{~mm})$ of hundreds of soil samples was analysed by Furtado (1983). Clay distributions fit different drainage conditions and(or) rainfall spans: smectite containing clays are dominant where drainage conditions are poor and(or) rainfall is low, while allophane/imogolite and gibbsite containing clays prevail where drainage is very good and(or) rainfall is high (Fig. 6). Input of Saharan dust is about $1.5 \mathrm{~g} /$ $\left(\mathrm{m}^{2} . \mathrm{y}\right)$ (Goudie and Middleton, 2001), with a mineral composition of about $20 \%$ quartz, $22 \%$ carbonates, $11 \%$ potassium feldspar, $10 \%$ plagioclase, and the rest consisting of amorphous phases, clays, Fe oxides and organic matter (reported for the nearest island Lanzarote by Hermann et al., 1996).

The majority of our water samples was collected at high altitudes (see Appendix) where the humidity is such that the andosols contain-in variable proportions-dominantly kaolinite-group minerals, vermiculite, gibbsite, amorphous aluminous (allophane type) and ferruginous phases, hematite, and minor amounts of organically bound $\mathrm{Al}$, magnetite and micas (Ricardo et al., 1992). Apart from inorganic phases, the soils are rather high in organic matter (predominantly fulvic type), in quite a few cases over $10 \%$ in the A-horizon down to a few percent in the C-horizon. Vermiculite has probably Al-hydroxide interlayers (Furtado, 1983; Nanzyo et al., 1993; Madeira et al., 1994). The Al to Si ratio in allophane ranges between $2: 1$ and $1: 1$. Al-rich allophane can be represented by the structural formula of imogolite $\left(\mathrm{Al}_{2} \mathrm{O}_{3} \cdot \mathrm{SiO}_{2} \cdot 2 \mathrm{H}_{2} \mathrm{O}\right)$ although the best empirical formula is $\mathrm{Al}_{2} \mathrm{O}_{3} \cdot 1.1 \mathrm{SiO}_{2} \cdot 2.3-$ $2.8 \mathrm{H}_{2} \mathrm{O}$ (Wada, 1985). Si-rich allophanes are not

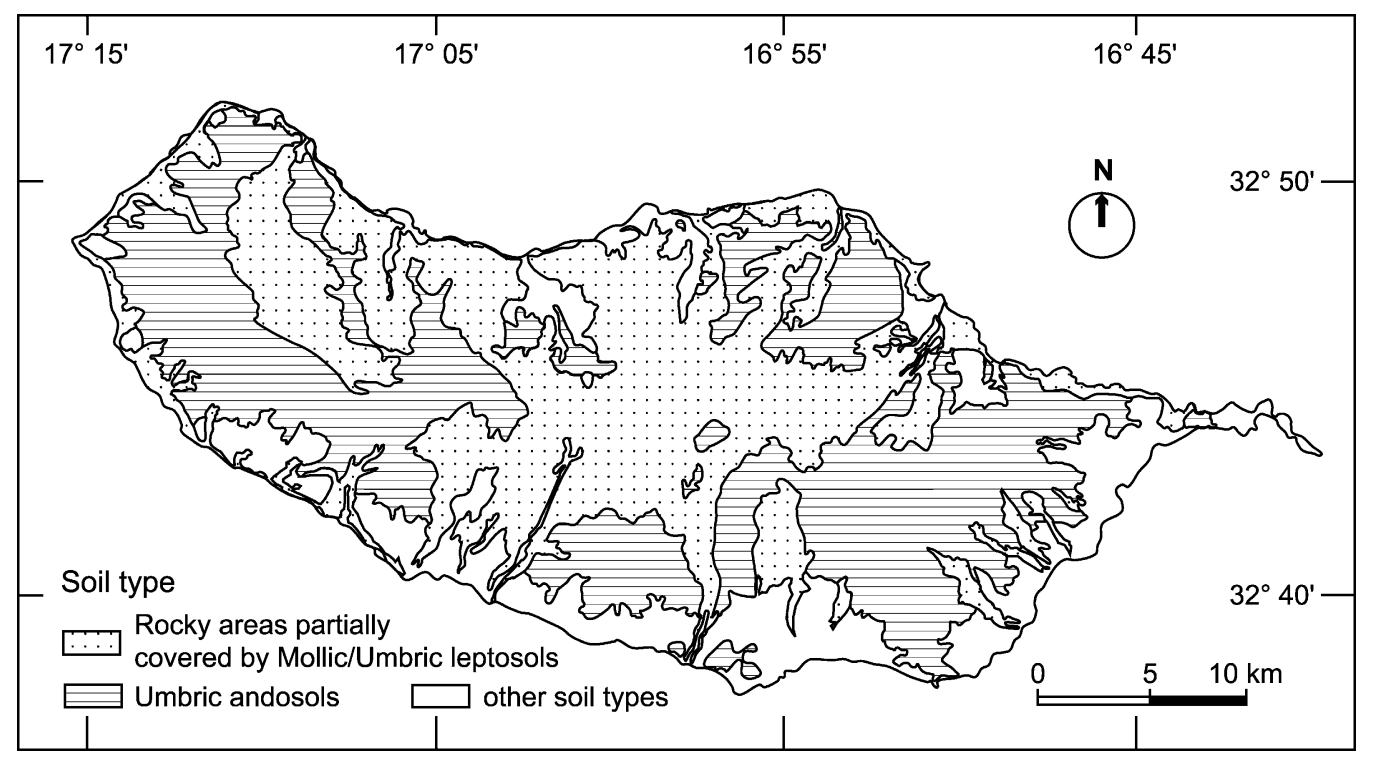

Fig. 5. Soil map of Madeira island; minor soil units concentrated along the coast were lumped together and are referred to as 'other' soil types; adapted from Ricardo et al. (1992). 


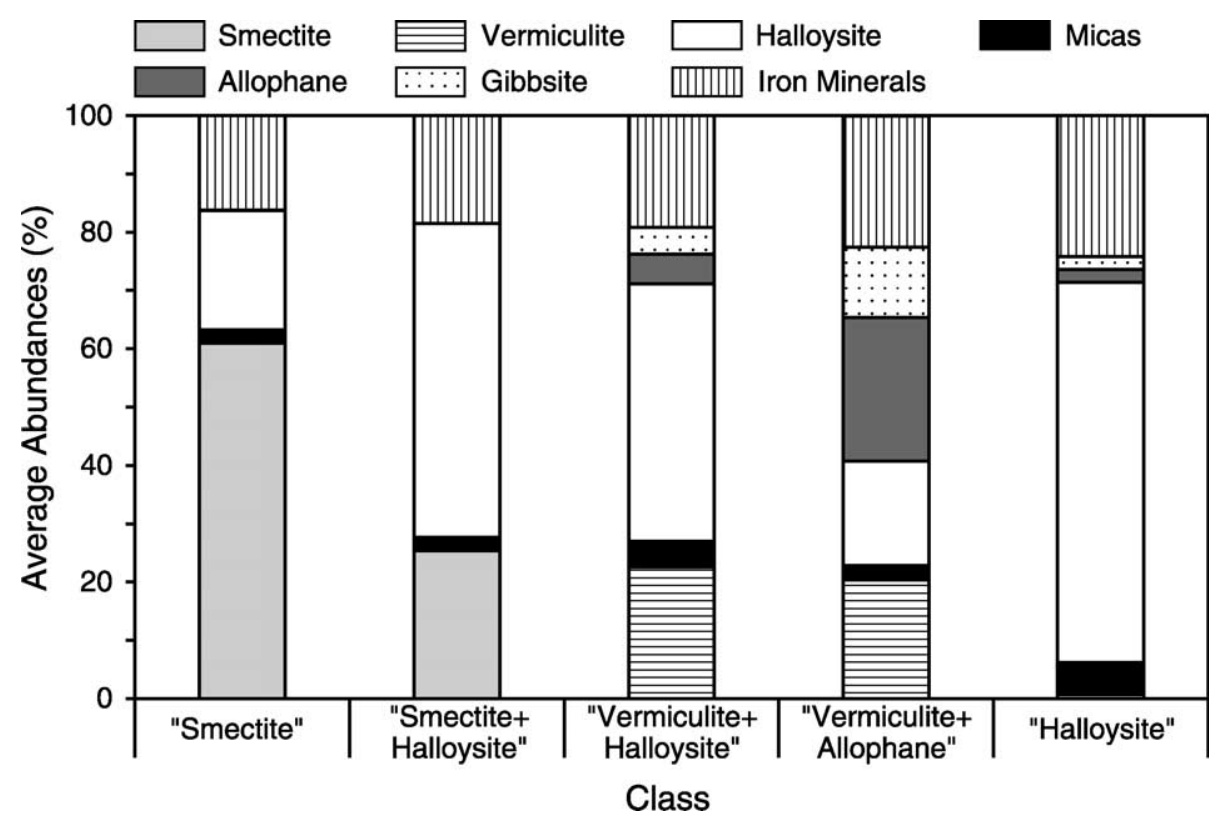

Fig. 6. Distribution of clay minerals and iron oxides in soils of the Madeira island; class names as defined by Furtado (1983). Montmorillonitecontaining clays are typically related to poor drainage conditions whereas allophane/imogolite- and gibbsite-containing clays are dominant under moderate to very good drainage conditions.

commonly found in andosols (Dahlgren et al., 1993). Fulvic compounds acidify the soil solution, readily form complexes with $\mathrm{Al}^{3+}$ released by weathering and may restrict the formation of allophane, especially in the A-horizon. Removal of organic acids, occurring in the B-horizon, leads to an increase of $\mathrm{pH}$ and decomplexation of $\mathrm{Al}^{3+}$, which allows for recombination of $\mathrm{Si}$, dissolved by weathering in the A- and B-horizons, with $\mathrm{Al}$ to form allophane (Dahlgren et al., 1993). On average, the enrichment of the andosols relative to the fresh rock is $2 \pm 0.3$ in $\mathrm{Al}_{2} \mathrm{O}_{3}$ and $1.5 \pm 0.5$ in $\mathrm{Fe}_{2} \mathrm{O}_{3}$. Since the ( \pm )-values pertain to one standard deviation, the enrichment factors for $\mathrm{Al}_{2} \mathrm{O}_{3}$ and $\mathrm{Fe}_{2} \mathrm{O}_{3}$ have a large overlap. For that reason, the assumption that $\mathrm{Al}$ and $\mathrm{Fe}$ are immobile in the weathering zone seems warranted. The concentrations of dissolved $\mathrm{Al}$ and $\mathrm{Fe}$ in our water samples were very low indeed. Ferric iron, produced by oxidative weathering, is immobilized as hematite (dominantly), ferrihydrite, minor amounts of poorly crystalline goethite and other noncrystalline hydrous oxides (Furtado et al., 1990), phases that chemically can be represented by $\mathrm{Fe}_{2} \mathrm{O}_{3} \cdot n \mathrm{H}_{2} \mathrm{O}$. Iron released without oxidation may be fixed as mixed $\mathrm{Fe}^{2+} \mathrm{Fe}^{3+}$ hydroxy compounds (Schwertmann and
Taylor, 1977). A problem raised by Madeira et al. (1994) is that hematite may not have been formed in the normal pedogenic cycle but rather represents a product from an earlier hydrothermal phase. However, in our model-to be presented in the sequelwe can ignore that.

\section{Sampling and analysis}

We collected 40 groundwater samples, as remote as possible from anthropogenic activities, at altitudes dominantly $>500 \mathrm{~m}$. Especially in the southern part of the island, surface water at lower altitudes is quite often highly polluted and for that reason not suited for study of natural weathering.

In the field, we measured temperature and electrical conductivity $(E C)$ and $\mathrm{pH}$ using portable instruments (Eijkelkamp, types 18.37 and 18.34). To avoid taking samples of polluted water, we semiquantitatively analysed the water for nitrate, using a Merckoquan nitrate-test 10050, and for phosphate, using an Aquamerck phosphate test PMB 14661. We filtered the waters through $0.4 \mu \mathrm{m}$ membrane filters, filled one clean 100-ml bottle for alkalinity 
titrations, another one for analysis of anions and dissolved silica, and a third one (acidified to $\mathrm{pH} 2$ ) for analysis of cations and dissolved silica. In the field laboratory, alkalinity was determined by titration with a $0.01 \mathrm{M} \mathrm{HCl}$ standard solution and using Gran plot end-point determination. In the home laboratory, the concentrations of the major cations, sulphur and silicon were determined by Inductively Coupled Plasma Atomic Emission Spectrometry (ICP-AES; Perkin Elmer Optima 3000) analysis, using specially prepared standard series in the proper concentration range. The relative precision of the results is better than $5 \%$ for $\mathrm{K}, \mathrm{Na}$, and $\mathrm{S}$, and $3 \%$ for $\mathrm{Mg}, \mathrm{Ca}$ and $\mathrm{Si}$. The concentrations of the anions $\mathrm{Cl}^{-}, \mathrm{SO}_{4}^{2-}$ and $\mathrm{NO}_{3}^{-}$were determined by Ion Chromatography (IC; Dionex QIC), using in-house standard series in the proper concentration range, with a precision better than $5 \%$ for $\mathrm{SO}_{4}^{2-}$ and $\mathrm{NO}_{3}^{-}$and $3 \%$ for $\mathrm{Cl}^{-}$. The results for $\mathrm{SO}_{4}^{2-}$ obtained by $\mathrm{IC}$ and those derived from $\mathrm{S}$ concentrations measured by ICP-AES agreed well. Dissolved silica was also measured in the unacidified sample using colorimetry (molybdenum blue method), the results of which compared very favourably with those derived from ICP-AES analyses. The charge balance between cations and anions, defined here as

$$
\begin{aligned}
& 200 \times(\{\Sigma[\text { cations }]-\Sigma[\text { anions }]\} /\{\Sigma[\text { cations }] \\
& +\Sigma[\text { anions }]\}) \%
\end{aligned}
$$

—where [ions] are the concentrations in meq/l-, was used as a check on the accuracy of the total analysis and considered acceptable when $<10 \%$.

\section{Hydrochemical results}

Our analytical results are listed in Appendix. EC values are predominantly $\leq 120 \mu \mathrm{S} / \mathrm{cm}$ (median $90 \pm 23 \mu \mathrm{S} / \mathrm{cm}$ ), with the exception of three samples with $E C$ values in the range of $150-175 \mu \mathrm{S} / \mathrm{cm}$. This means that the waters are low in solutes and ionic strength. The $\mathrm{pH}$ values are mostly in the basic range (median $\mathrm{pH} 7.6 \pm 0.45 ; 3$ samples with $\mathrm{pH}<6.5$ ), higher than the acid $\mathrm{pH}$ typical for the andosols, which means that they have acquired alkalinity by interaction with reactive minerals in the $\mathrm{C}$-horizons or the bedrock. Still, the $P_{\mathrm{CO}_{2}}{ }^{2}$ is predominantly higher (median $P_{\mathrm{CO}_{2}}=10^{-3.2 \pm 0.47}$ atm; 2 samples with $P_{\mathrm{CO}_{2}}>10^{-2}$ atm) than the atmospheric value $\left(P_{\mathrm{CO}_{2}}=10^{-3.5} \mathrm{~atm}\right)$, which must be a relic of the usually high soil- $P_{\mathrm{CO}_{2}}$. Very similar patterns of $\mathrm{pH}$ and $P_{\mathrm{CO}_{2}}$ (after recalculation, however, from their $\left[\mathrm{HCO}_{3}^{-}\right]$and $\mathrm{pH}$ values) have been reported by Almeida et al. (1984). The relation between the seasalt-corrected cation concentrations (labelled by an*) and bicarbonate is shown in Fig. 7. Clearly, $\mathrm{Mg}^{2+}$ and $\mathrm{Ca}^{2+}$ are the dominant cations. Our samples were collected in the summer season (late June, early July). Based on data reported by Prada (2000), the following ratios of summer to annual concentrations (using median values in meq/l for ions and in $\mathrm{mmol} / \mathrm{l}$ for dissolved silica) are calculated: $\left[\mathrm{Na}^{+}\right]^{*}(1.4),\left[\mathrm{K}^{+}\right]^{*}$ (1.15), $\left[\mathrm{Mg}^{2+}\right]^{*}(1.07),\left[\mathrm{Ca}^{2+}\right]^{*}(0.95),\left[\mathrm{HCO}_{3}^{-}\right]$ (0.99), $\left[\mathrm{Cl}^{-}\right](0.98),\left[\mathrm{SO}_{4}^{2-}\right]^{*}(1.25)$ and $\left[\mathrm{H}_{2} \mathrm{SiO}_{3}^{0}\right]$ (1.52). Although these values are derived from analyses of water samples collected during only one full year (1992/1993), they can be used to convert summer concentrations into annual concentrations. However, median summer concentrations (ions in $\mathrm{meq} / \mathrm{l}$, silica in $\mathrm{mmol} / \mathrm{l}$ ) reported by Prada (first number) are not equal to ours (second number): $\left[\mathrm{Na}^{+}\right]^{*}(0.08,0.13),\left[\mathrm{K}^{+}\right]^{*}(0.01,0.01),\left[\mathrm{Mg}^{2+}\right]^{*}$ $(0.35,0.26),\left[\mathrm{Ca}^{2+}\right]^{*}(0.39,0.29),\left[\mathrm{HCO}_{3}^{-}\right](0.56$, $0.69),\left[\mathrm{Cl}^{-}\right](0.28,0.21),\left[\mathrm{SO}_{4}^{2-}\right]^{*}(0.013,0.003)$, $\left[\mathrm{H}_{2} \mathrm{SiO}_{3}^{0}\right](0.40,0.33)$. A reason for the discrepancies is the fact that her and our samples were not collected in the same year nor at the same sites. Also, the charge balances of the median ionic concentrations in Prada's data set for winter $(+30 \%)$ and summer $(+25 \%)$ are not very good. ${ }^{3}$ Moreover, the differences in the median summer values of $\left[\mathrm{Mg}^{2+}\right] * /\left[\mathrm{Ca}^{2+}\right]^{*}(0.9,0.5)$ and $\left[\mathrm{HCO}_{3}^{-}\right] /\left[\mathrm{H}_{2} \mathrm{SiO}_{3}^{0}\right](1.4,1.9)$ indicate that the sampled waters do not represent exactly the same weathering reactions. Therefore, the ratios of summer to annual concentrations have uncertainties, which are arbitrarily estimated in the order of $30 \%$ relatively. Higher values of $\left[\mathrm{Mg}^{2+}\right]^{*} /\left[\mathrm{Ca}^{2+}\right]^{*}$ (but without

\footnotetext{
${ }^{2} \log P_{\mathrm{CO}_{2}}$ was calculated from $\mathrm{pH}$ and bicarbonate activity using stability constants corrected for temperature (Langmuir, 1997).

${ }^{3}$ Because fluoride concentrations were only measured in a few of her samples, the contribution of the contribution of $\mathrm{F}^{-}$was ignored, which otherwise would have improved the ion balance a little. We did not analyze $\mathrm{F}^{-}$in our samples, but still our ion balances are $<10 \%$.
} 


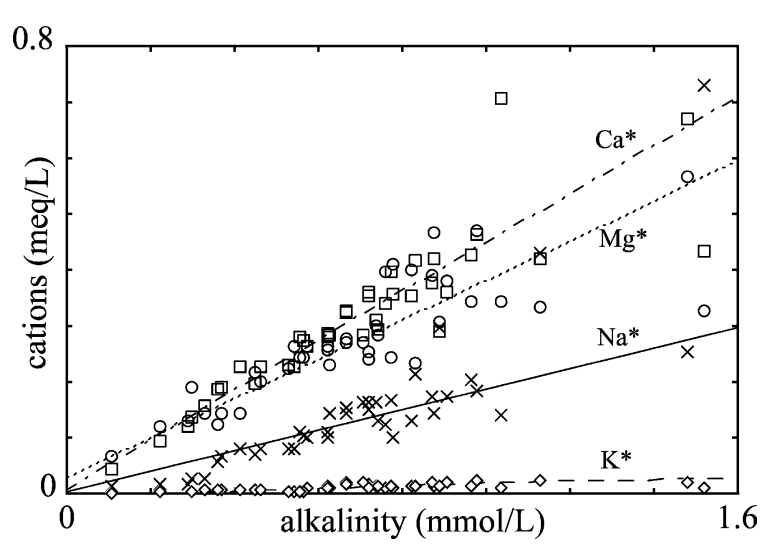

Fig. 7. Plot of the major cation concentrations (corrected for sea-salt contributions) versus alkalinity. The $\left[\mathrm{K}^{+}\right]^{*},\left[\mathrm{Mg}^{2+}\right]^{*}$ and $\left[\mathrm{Ca}^{2+}\right]^{*}$ data were fitted by reduced-major-axis regression (Rollinson, 1993), the $\left[\mathrm{Na}^{+}\right]^{*}$ data were fitted visually neglecting some outliers. Note that the lines are forced through zero, assuming that $\mathrm{HCO}_{3}^{-}$is the only anion compensating for the sea-salt-corrected cation concentrations. The scatter of the data is particularly great at high alkalinity.

specification of the season) have been reported by Almeida et al. (1984) $(1.53 \pm 1.01)$ and by Silva (1988) (between 1 and 2). The median value of

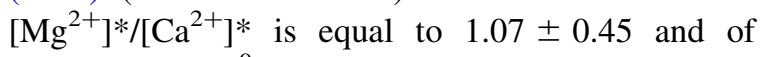
$\left[\mathrm{HCO}_{3}^{-}\right] /\left[\mathrm{H}_{2} \mathrm{SiO}_{3}^{0}\right]$ to $1.19 \pm 0.50$. Our water samples are all highly undersaturated with respect to calcite, so it is unlikely that the $\left[\mathrm{Mg}^{2+}\right] * /\left[\mathrm{Ca}^{2+}\right]^{*}$ value is affected by calcite precipitation. The presence of calcite in the soil profiles in the area has not been reported; this means that carbonate supplied by dust is readily dissolved. The share of anions other than $\mathrm{HCO}_{3}^{-}$in the total anion concentration (all in meq/l) is quite large $(50 \pm 12 \%)$ in the data set of Almeida et al. (1984), but about equal in Prada's (2000) (36 $\pm 12 \%)$ and our $(30 \pm 9 \%)$ data sets. This means that our samples represent chemical weathering somewhat better, although there is still a large presence of sea salt. No clear relation exists between $\left[\mathrm{SO}_{4}^{2-}\right]$ and $\left[\mathrm{Cl}^{-}\right]$(Fig. 8). Correction of $\left[\mathrm{SO}_{4}^{2-}\right]$ for sea-salt contributions leads in $25 \%$ of our samples to negative values. In precipitation on Iceland, $\mathrm{SO}_{4}^{2-}$ concentrations are generally higher than predicted from a marine contribution, but in some samples they were also lower (Gíslason et al., 1996). Positive values can be caused by contributions from decaying vegetation, from dimethylsulphide (Bates and Cline, 1985; Luria et al., 1989) produced by marine algae, by input of

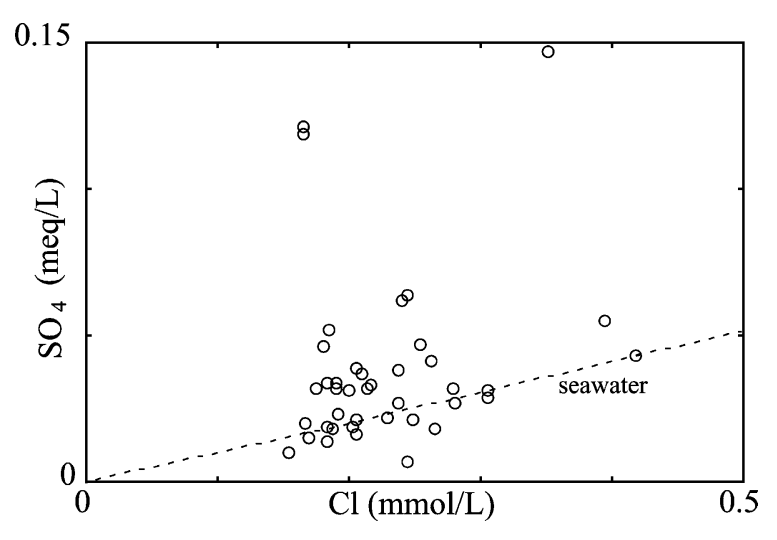

Fig. 8. Plot of sulfate against chloride concentrations. The solid line represents the ratio in sea salt. Note that in a number of samples seasalt correction gives negative sulfate concentrations.

non-sea-salt sulphate in aerosols (Rodrigues et al., 2001) and possibly by air pollution from abundant combustion of fossil fuel on Madeira. Negative $\left[\mathrm{SO}_{4}^{2-}\right]^{*}$ values may be due to overcorrecting, to sorption of $\mathrm{SO}_{4}^{2-}$ in the soil profile (Li, 1988) and(or) net consumption by vegetation. Although it does not solve this problem, we note that negative values are also found in the data sets of Prada (2000) and Almeida et al. (1984). Nitrate concentrations are predominantly very low (median $0.2 \mu \mathrm{M}$ ), lower than in average rain water in oceanic regions $(\approx 1 \mu \mathrm{M}$; Gíslason et al., 1996), but nitrate is also consumed by vegetation. In six samples $\left[\mathrm{NO}_{3}^{-}\right]>10 \mu \mathrm{M}$, but still relatively small in comparison with the combined other anions. We tried hard to avoid sampling of polluted waters, so a higher $\left[\mathrm{NO}_{3}^{-}\right]$is probably derived from decay of plant material, from the occasional presence of cattle, or from air pollution. Since bicarbonate and dissolved silica are solely derived from chemical weathering, it can be expected that the relation between these species depends on the interaction of percolating water with the mineral assemblage in the weathering profile. Relations between the concentrations of these species are portrayed in Fig. 9, showing a wide envelope of relations related to weathering reactions involving dissolution of primary minerals and production of secondary phases. The power fit of the data suggests a relative decrease of the release of silica upon an increase in alkalinity. In terms of weathering this means that relatively poor drainage conditions show a build-up of alkalinity and further the preservation of 


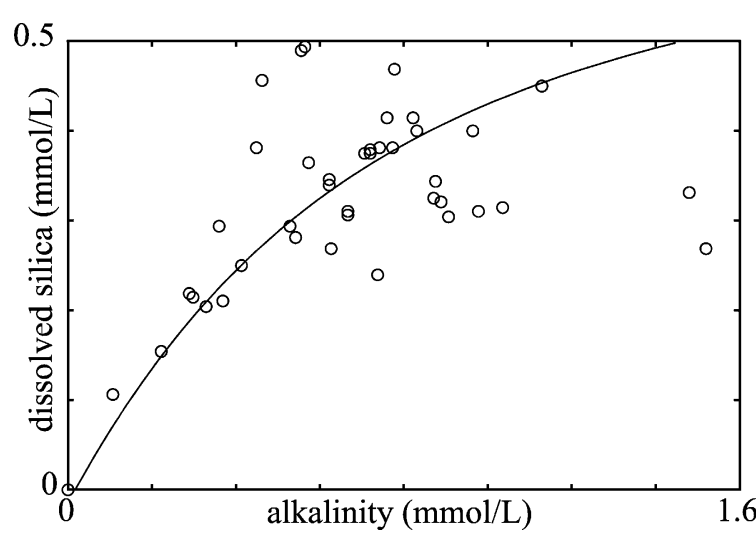

Fig. 9. Plot of concentrations of dissolved silica against alkalinity. Both species are intimately related to chemical weathering only. The power-function fit of the scattered data serves only to visualize an average trend.

silicon in secondary minerals. In the following section, these relations will be used to reconstruct the relative contributions of the various minerals to the water chemistry. As a preliminary note it has to be recalled that our data represent summer, not annual concentrations. For that reason, our data represent base flow concentrations. Solutions in low-permeability channels and intragranular pores have a relatively long residence time and are representative of slow flow conditions. Conversely, under rapid flow conditions in the wet season, solutions move largely through high-permeability channels which represent only a small fraction of the total surface area (Velbel, 1993; Drever and Clow, 1995; Drever, 1997). The differences between the ratios of summer to annual elemental concentrations are likely caused by mixing of water with different residence times and having been in contact with different surfaces. Additionally, it has to be realized that a high, if not very high, percentage of the potentially available mineral surface area in soils may not participate in reactions and contribute to the composition of water effluxes (Velbel, 1993).

\section{Model approach}

\subsection{Conceptual geochemical model}

Given their abundances and resistance to weathering, we assume that among the rock forming minerals listed in Table 1, only olivine, pyroxene and plagioclase contribute significantly to the natural composition of spring waters. From analysis of Fig. 6, we further assume that (1) iron oxides are produced by weathering of olivine and pyroxene in all drainage scenarios; (2) under poor drainage conditions (first two classes in Fig. 6), pyroxene and plagioclase weather to mixtures of smectite plus halloysite; (3) moderate to good drainage conditions (next two classes) change the pattern of weathering by introducing vermiculite, allophane and gibbsite into the clay fraction. Under moderate drainage conditions, pyroxene alters to mixtures of vermiculite plus halloysite whereas plagioclase weathers mostly to mixtures of halloysite plus allophane. When subject to more effective flushing, pyroxene maintains its set of secondary products while plagioclase is leached more intensively, producing mixtures with allophane plus gibbsite; (4) very good drainage conditions (last class) are characterised by the disappearance of intermediate secondary minerals (vermiculite) from the clay fraction. Such disappearance implies a progress in the leaching of pyroxene, that now weathers to mixtures of halloysite plus allophane, while plagioclase keeps producing mixtures with allophane plus gibbsite. Since we are interested in chemical mass balances rather than in the precise compositions of the soil constituents, we represent amorphous aluminous and ferruginous phases by the metal oxides of the corresponding crystallized mineral phases (Table 2). In our model we also assume a steady-state vegetation within the area of sample collection. Our samples are from areas not in use by agriculture, so we only neglect net release or uptake of elements by (de)forestation, which is believed to be of minor, if any, importance in this area. We do not include the effect of sorption of cation on soil components, assuming the soil to be in steady state with respect to occupancy of reactive surface sites. The relatively high contribution of sea salt to the soil solution will have a dominant effect on the distribution and composition of the surface complexes in the soil.

The mixtures of clay minerals produced from each primary mineral under the different drainage conditions are summarized in Fig. 10; the end member reactions (the ones producing just one clay) are listed in Table 3. In addition to the assumptions made, we 
Table 2

Minerals and their composition in major soil types (Fig. 5). Saponite and nontronite from Deer et al. (1974), vermiculite based on McBride (1994); Sparks (1995)

\begin{tabular}{ll}
\hline Mineral phases & $\begin{array}{l}\text { Chemical composition in } \\
\text { mineral-forming oxides } \\
\text { (structural } \mathrm{H}_{2} \mathrm{O} \text { omitted) }\end{array}$ \\
\hline $\begin{array}{l}\text { Smectites: } \\
\text { Saponite }\end{array}$ & $0.33 \mathrm{CaO} \cdot 6 \mathrm{MgO} \cdot 0.33 \mathrm{Al}_{2} \mathrm{O}_{3} \cdot 7.34 \mathrm{SiO}_{2}$ \\
$\begin{array}{l}\text { Nontronite } \\
\text { Vermiculite }\end{array}$ & $0.33 \mathrm{CaO} \cdot 2 \mathrm{Fe}_{2} \mathrm{O}_{3} \cdot 0.33 \mathrm{Al}_{2} \mathrm{O}_{3} \cdot 7.34 \mathrm{SiO}_{2}$ \\
$\begin{array}{l}\text { Mica } \\
\text { Halloysite, other } \\
\text { kaolinite-group } \\
\text { minerals and allophane }\end{array}$ & $0.35 \mathrm{MgO} \cdot 0.15 \mathrm{Fe}_{2} \mathrm{O}_{3} \cdot \mathrm{Al}_{2} \mathrm{O}_{3} \cdot 3.6 \mathrm{SiO}_{2}$ \\
$\begin{array}{l}\text { Imogolite and Al-rich } \\
\text { allophanes }\end{array}$ & $0.62 \mathrm{~K}_{2} \mathrm{O} \cdot 2.63 \mathrm{Al}_{2} \mathrm{O}_{3} \cdot 6.75 \mathrm{SiO}_{2}$ \\
$\begin{array}{l}\text { Gibbsite and amorphous } \\
\text { aluminous phases }\end{array}$ & $\mathrm{Al}_{2} \mathrm{O}_{3} \cdot 2 \mathrm{SiO} \mathrm{O}_{2}$ \\
$\begin{array}{l}\text { Hematite and other } \\
\text { ferruginous phases }\end{array}$ & $\mathrm{Al}_{2} \mathrm{O}_{3} \cdot 1.1 \mathrm{SiO}_{2}$ \\
\hline
\end{tabular}

note that if-for the reason that they are less weathered and compacted-younger geological units are better groundwater conduits than older andbecause of genetic factors-basaltic flows transmit water faster than pyroclastic materials, then a link is expected between poor drainage conditions and B1 and B2 as well as between moderate to very good drainage conditions and B2 to B5 (Fig. 10).

We can also imagine how mineral weathering rates are distributed among the geological complexes. They are not only dependent on the residence times of groundwater (traced by alkalinity) but also on the volume of water percolating through the soil and

\begin{tabular}{|c|c|c|c|c|}
\hline \multirow{3}{*}{ Primary Mineral } & \multicolumn{4}{|c|}{$\begin{array}{c}\text { Drainage Conditions and } \\
\text { Associated Geological Complex(es) }\end{array}$} \\
\hline & Poor & Moderate & Good & Very Good \\
\hline & $\mathrm{B} 1-\mathrm{B} 2$ & \multicolumn{3}{|c|}{ B2-B5 } \\
\hline \multirow{2}{*}{\multicolumn{5}{|c|}{ Plagioclase }} \\
\hline & & & & \\
\hline \multirow{3}{*}{ Pyroxene } & & & & \\
\hline & & & & 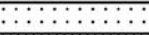 \\
\hline & & & & |||||||| \\
\hline \multicolumn{5}{|l|}{ Olivine } \\
\hline Smectite & & Halloysite & & Gibbsite \\
\hline Vermiculite & ..... & Allophane & Ш & Iron Oxides \\
\hline
\end{tabular}

Fig. 10. Conceptual weathering model for Madeira island. Under different drainage regimes, diverse assemblages of secondary phases are produced by weathering of the major primary minerals. bedrock during a certain period of time (traced by $R$ ). In Fig. 11a, we plotted $R$ (right axis) and alkalinity (left axis) in the $\mathrm{B} 1-\mathrm{B} 4$ complexes. The product of $R$ and $\left[\mathrm{HCO}_{3}^{-}\right]$values is the export rate of bicarbonate (Fig. 11b) which can be considered as a measure of the weathering rate. It suggests a significant decrease in the weathering rates from $\mathrm{B} 1$ to $\mathrm{B} 2$, a steady increase from B2 to B3 and another decrease from B3 to $\mathrm{B} 4$.

\subsection{Data analysis}

Our conceptual geochemical model (Fig. 10) assumes that the weathering of plagioclase and pyroxene produces mixtures of secondary minerals (e.g. halloysite plus allophane) described by combinations of end member reactions (e.g. $c \times R_{7}+(1-$ $c) \times R_{8}$, with $0 \leq c \leq 1 ; R_{7}$ and $R_{8}$ are reaction numbers as defined in Table 3 ). The purpose is to optimise the $c$ values, i.e. to identify the best combinations of single product reactions.

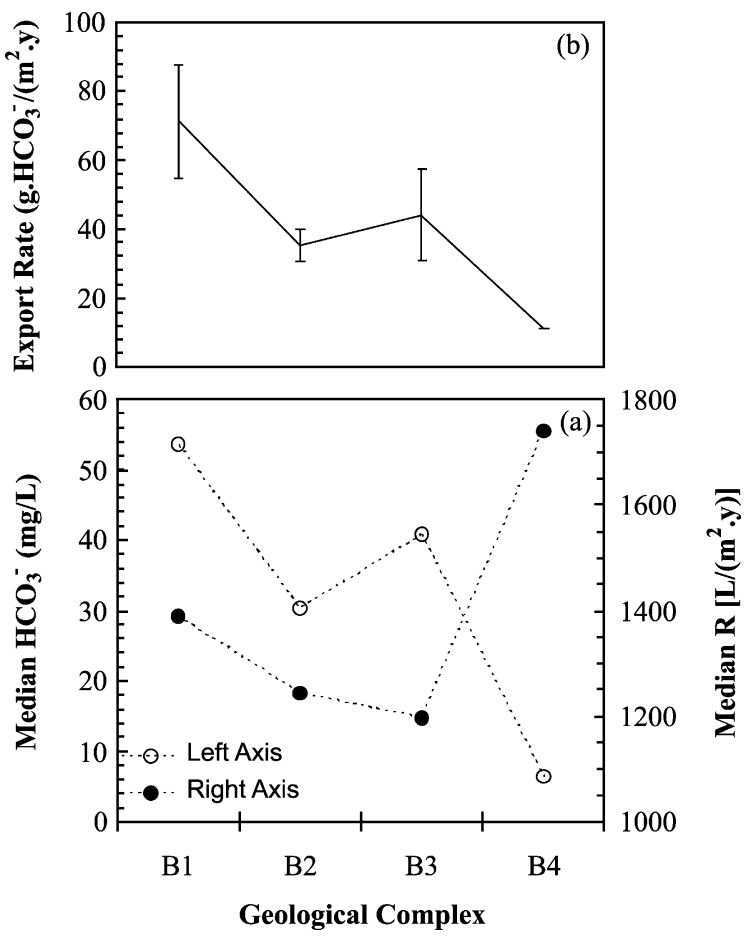

Fig. 11. (a) Average recharge rates and alkalinities for the complexes B1-B4, and (b) average export rates of bicarbonate, calculated as the product of recharge rate times alkalinity. 
The SiB algorithm has been used, a mole balance model introduced by Pacheco and Van der Weijden (1996) and extended by Pacheco et al. (1999); Pacheco and Van der Weijden (2002). Like other similar models (e.g. Bowser and Jones, 2002), the SiB algorithm solves a set of mole balance equations, $A X=B$, but the structure of matrix $A$ and of vectors $X$ and $B$ in our case provides flexibility to deal with situations where not all contributions to groundwater chemistry are stoichiometrically constrained, and the iterative loops implemented allow for the analysis of scenarios where primary minerals have variable composition (e.g. plagioclase) and weather to endmember as well as to combinations of secondary products. A description of $B, A$ and $X$ is given in the following paragraphs.

Vector $B$-is an input vector with the chemical composition of a spring (major inorganic compounds, Appendix). The vector has seven rows corresponding to the molar concentrations of $\mathrm{HCO}_{3}^{-}, \mathrm{H}_{2} \mathrm{SiO}_{3}, \mathrm{Na}^{+}, \mathrm{K}^{+}, \mathrm{Mg}^{2+}$ and $\mathrm{Ca}^{2+}$ (first six rows) and to the sum in equivalents of $\mathrm{Cl}^{-}, \mathrm{SO}_{4}^{2-}$ and $\mathrm{NO}_{3}^{-}$(三 Pollution, last row). The first six rows are assigned to dissolved compounds which are totally $\left(\mathrm{HCO}_{3}^{-}\right.$and $\left.\mathrm{H}_{2} \mathrm{SiO}_{3}\right)$ or in part (cations) derived from weathering reactions of silicate minerals whereas the last row lumps together the compounds derived from other sources (mostly atmospheric and anthropogenic);

Matrix $A$-is an input matrix of coefficients, which is column divided as well as row divided: (column division) the first $k$ columns represent chemical weathering, one column reserved for each primary mineral. The remaining $m-k$ columns account for contributions other than weathering, which are classified as undetermined because in those cases it is hard (even impossible) to set stoichiometric relations between the dissolved compounds and the reactant phases involved (e.g. the case of anthropogenic inputs). The value for $k$ is set by the number of primary minerals (in the present case three:olivine, plagioclase and pyroxene) while $m-k$ is set by the number of dissolved compounds which play a role in weathering as well as in the other contributions (the four cations); (row division). As for vector $B$, the first six rows of matrix $A$ represent bicarbonate, silica and the four major cations. In combination with vector $B$ (and vector $X$ described below), these rows form a set of mole balance equations, one for each dissolved compound. On the other hand, the last row is a charge balance equation that matches Pollution with a concomitant concentration of cations.

The column and row divisions mentioned above break matrix $A$ into four different sectors. In sector one (first $k$ columns combined with the first six rows) the elements of $A$ are stoichiometric ratios between dissolved compounds and reactant phases, as determined by the weathering reactions (Table 3 ). In sector two (last $m-k$ columns $\times$ first six rows), the elements of $A$ are one if a contribution to sources other than weathering is to be accounted or zero otherwise. In sectors three (first $k$ columns $\times$ last row) and four (last $m-k$ columns $\times$ last row) the elements of $A$ are zero and one, respectively.

Vector $X$-is the output vector, which represents the mole fractions of the dissolved primary minerals (first $k$ rows) and the number of moles of cations not assigned to weathering reactions (the so called residual concentrations, last $m-k$ rows).

A set of weathering reactions is said to be valid-it explains the composition of a spring-when $X>0$ for all elements in vector $X$. Whenever there is more than one valid set of weathering reactions for a given spring, the model selects one best fit set by checking all possible sets against predefined boundary conditions. In the present case, because all spring water samples are free of anthropogenic inputs and therefore total chloride and residual sodium may be attributed to wet and dry deposition of marine aerosols, the best fit weathering reactions of each water sample were those leading to $\left[\mathrm{Cl}^{-}\right]_{\mathrm{t}} /\left[\mathrm{Na}^{+}\right]_{\mathrm{u}} \approx 1.17$, where []$_{\mathrm{t}}$ and [ ] denote total and residual concentrations, respectively, and 1.17 is the $\left[\mathrm{Cl}^{-}\right]$to $\left[\mathrm{Na}^{+}\right]$mole ratio in sea salt.

The weathering rate $\left(W_{\mathrm{X}}\right)$ of a primary mineral $(\mathrm{X})$ can be calculated by:

$W_{\mathrm{X}}\left[(\mathrm{mol} /(\right.$ ha $\mathrm{y})]=[\mathrm{X}](\mathrm{mol} / \mathrm{l}) \times R(\mathrm{~mm} / \mathrm{y}) \times 10^{4}$

where $[\mathrm{X}]$ is the concentration of dissolved $\mathrm{X}$ and $R$ is the annual recharge in the catchment of the spring. The mole fractions were computed by the $\mathrm{SiB}$ model and the recharge rates by Eq. (2f). To account for abundance in the rock when comparing weathering rates among different minerals, the $W_{\mathrm{X}}$ values may further be normalized by the bulk percentages of 
Table 3

Weathering reactions of Plagioclase (Pl), Pyroxene (Py) and Olivine (Ol); $\mathrm{x}$ is the anorthite fraction in $\mathrm{Pl}$, and 'av' and 'bord' are the average and border compositions of $\mathrm{Ol}$

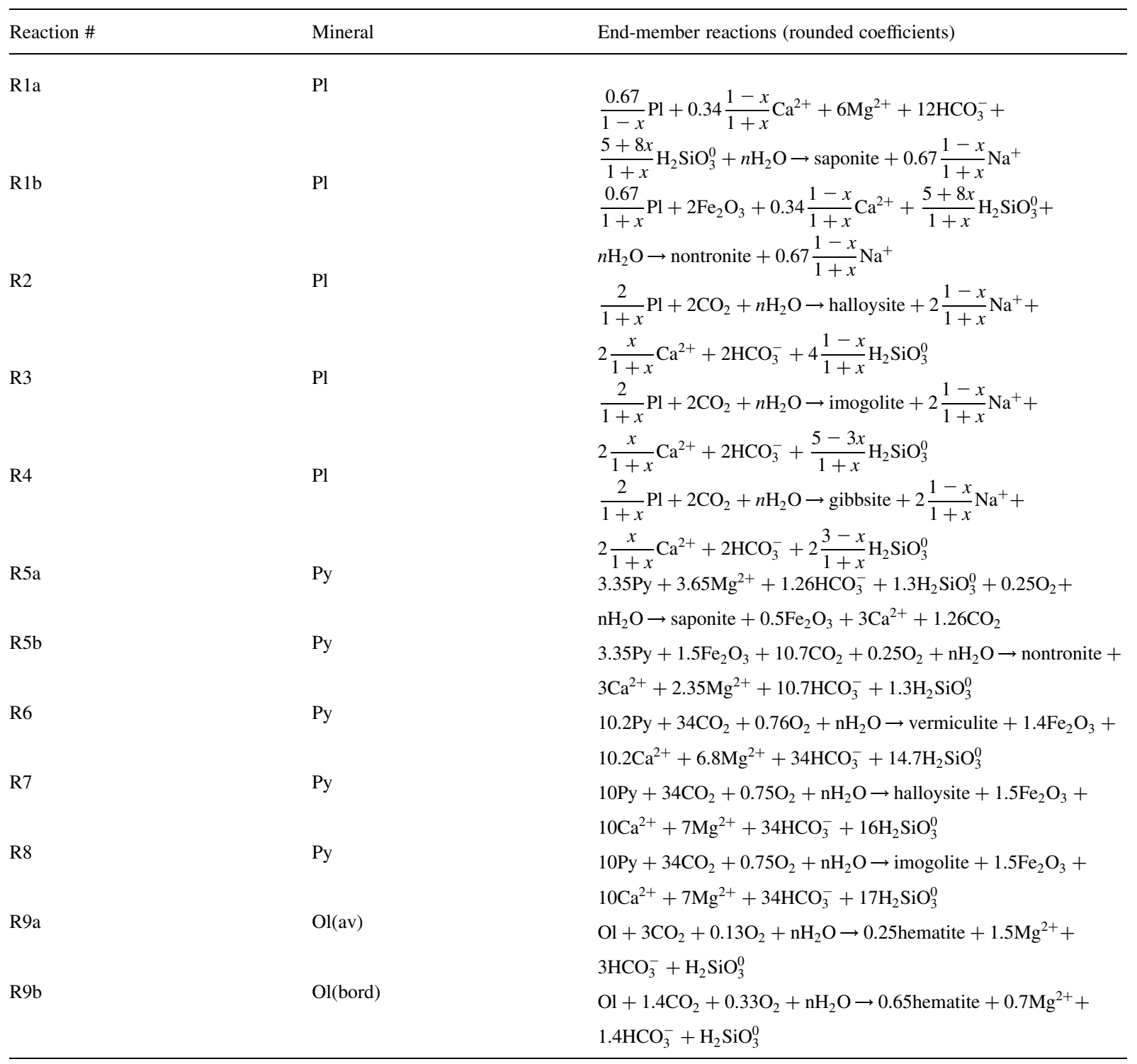

element $\mathrm{X}$ in the rock, which give rates in $\mathrm{mol} /$ (ha y vol\%mineral).

\subsection{Model results and discussion}

Although Fig. 10 links poor drainage conditions to springs in B1-B2 and moderate to very good drainage conditions to springs in $\mathrm{B} 2-\mathrm{B} 5$, we checked all springs against the four drainage scenarios included in the conceptual geochemical model. Further, because we did not know the chemical composition of Madeira smectites and wanted to check the influence of olivine zonation in the results of the $\mathrm{SiB}$ algorithm, we repeated the calculations considering the following four scenarios: (1) Smectites are represented by saponite 
(Table 2) and olivines by the structural formula of their border composition $\left(0.7 \mathrm{MgO} \cdot 1.3 \mathrm{FeO} \cdot \mathrm{SiO}_{2}\right)$; (2) Smectites are represented by saponite but olivines by their average formula (Table 1); (3) Smectites are represented by nontronite (Table 2) and olivines by their border composition; (4) Smectites are represented by nontronite and olivines by their average composition.

The results of these scenarios, regarding weathering rates of plagioclase, pyroxene and olivine are shown in Fig. 12a-d. Additionally, we plotted a weathering intensity index (WII) computed as follows: (1) For each spring in a geological complex, we assigned a WII between 1 and 4 depending on whether the spring has been connected by the $\mathrm{SiB}$ algorithm to poor $(\mathrm{WII}=1)$, moderate $(\mathrm{WII}=2)$, good $(\mathrm{WII}=3)$ or very good $(\mathrm{WII}=4)$ drainage conditions (Fig. 12a); (2) Next, we calculated the average WII taking into account the WIIs of each spring; (3) Finally, an integer value of the average WII is linked to the complex for a specific drainage scenario (e.g. moderate drainage for $\mathrm{WII}=2$ ), a real value for an intermediate drainage scenario (e.g. moderate to good drainage for WII $=2.3$ ).

In the first scenario (Fig. 12a), we were unable to match the water chemistries of springs in B1 and B4 with any set of weathering reactions. In the other complexes, weathering rates are in the sequence $\mathrm{Ol}>>\mathrm{Pl}\left(\mathrm{An}_{55-65}\right)>\mathrm{Py}$ (Goldich sequence) but the average WIIs (1.2 and 1.3) do not represent the presumed moderate to very good drainage conditions (Fig. 10) nor is the pattern of weathering rates in agreement with Fig. 11b. Moreover, only $50 \%$ of the water chemistries could be explained in this scenario. In the second scenario (Fig. 12b), the WIIs are consistent with the geochemical model, the pattern of weathering rates matches that of Fig. 11b (B2-B4 complexes), but there is no reason why the sequence of susceptibilities to weathering would change significantly from $\mathrm{B} 1(\mathrm{Ol}>>\mathrm{Pl}>\mathrm{Py})$ to $\mathrm{B} 2-\mathrm{B} 4$ $(\mathrm{Pl}>\mathrm{Ol}>\mathrm{Py}$ ). In the third scenario (Fig. 12c), the picture is identical to that of the first one. However, the number of spring water chemistries that could be explained in scenarios 2 and 3 increases to about 75

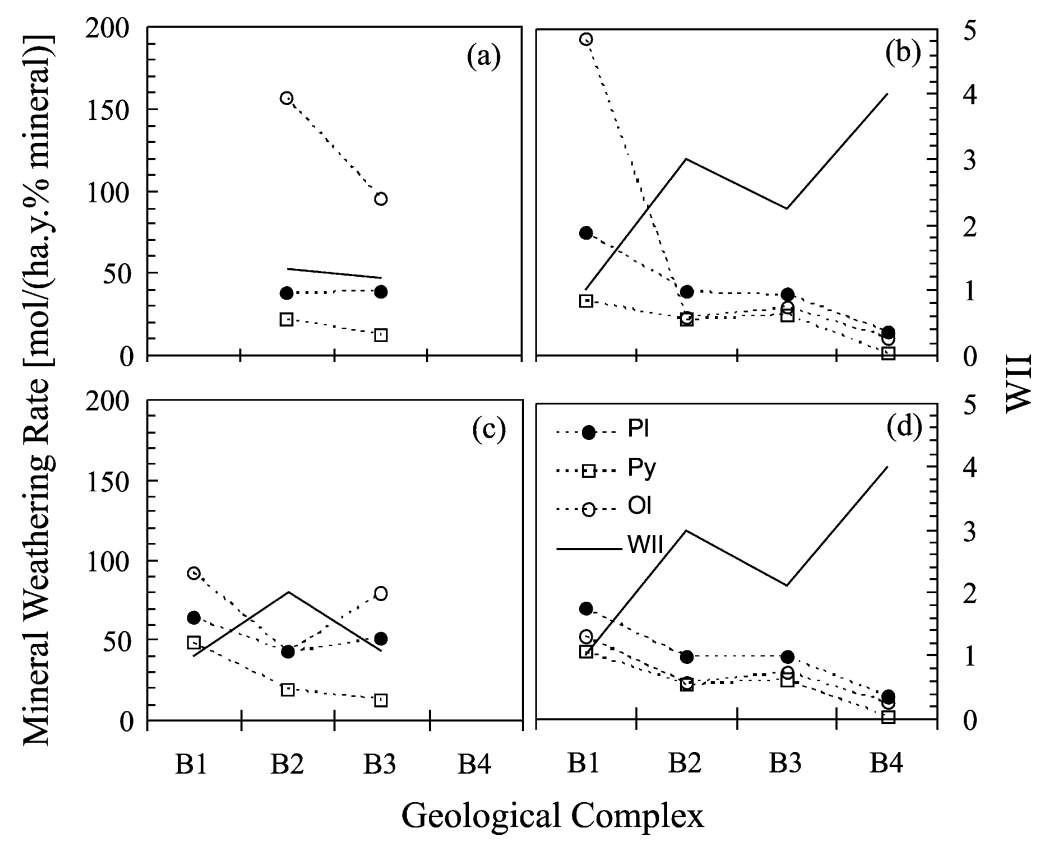

Fig. 12. Average weathering rates of plagioclase (Pl), pyroxene (Py), olivine (Ol) in the various geological complexes of Madeira island in four weathering scenarios: (a) smectite is represented by saponite, olivine by the composition of the border of the minerals; (b) smectite is represented by saponite, olivine by its bulk composition; (c) smectite is represented by nontronite, olivine by the composition of the border of the minerals; (d) smectite is represented by nontronite, olivine by its bulk composition. WII is the weathering intensity index (consult text for a detailed description). 
and $65 \%$, respectively In the fourth scenario (Fig. 12d) we find a close agreement between the WIIs and the expected drainage conditions as well as between actual and predicted patterns of weathering rates (Fig. 11b). This is why we adopted this fourth scenario and its model results as the most realistic one.

The results of the $\mathrm{SiB}$ algorithm are summarized in Table 4:, springs were assembled according to the proposed drainage scenarios (column 1); sample numbers and associated geological complexes are shown in columns 2 and 3; in total, 33 out of 40 samples $(83 \%)$ have their chemical compositions explained by the model, and the best fit sets of weathering reactions comply with $\left[\mathrm{Cl}^{-}\right]_{\mathrm{t}} /$ $\left[\mathrm{Na}^{+}\right]_{\mathrm{u}}=1.09 \pm 0.11$ (column 4 ), in good agreement with the value of 1.17 in sea salt. Complimentary to this boundary condition, the median $\left[\mathrm{Cl}^{-}\right]_{\mathrm{t}} /\left[\mathrm{Mg}^{2+}\right]_{\mathrm{u}}$ as well as the median $\left[\mathrm{Cl}^{-}\right]_{\mathrm{t}} /\left[\mathrm{Ca}^{2+}\right]_{\mathrm{u}}$ mole ratios have been compared with their marine counterparts (10.3 and 51.9). For the first ratio we obtained a value of 11.9 , for the second a value of 49.9 .

\subsection{Weathering reactions}

Under poor drainage conditions, both plagioclase and pyroxene produce mixtures of nontronite plus halloysite $\left(0.1 \mathrm{R}_{1 \mathrm{~b}+} 0.9 \mathrm{R}_{2}\right.$ and $0.6 \mathrm{R}_{5 \mathrm{~b}+} 0.4 \mathrm{R}_{7}$; Table 4 columns 6 and 7), but the mixtures are richer in halloysite when derived from plagioclase $(90 \%$ halloysite in the mixture) than when derived from pyroxene $(40 \%)$. This suggests that plagioclase is being leached faster than pyroxene. The predicted smectite and halloysite abundances (columns 8 and 10) are consistent with those of class 'Smectite + Halloysite' (Fig. 6).

Under moderate drainage conditions, weathering produces '1:1 mixtures' of halloysite plus Al-rich allophane (plagioclase: $0.6 \mathrm{R}_{2}+0.4 \mathrm{R}_{3}$ ) or vermiculite plus halloysite (pyroxene: $0.5 \mathrm{R}_{6}+0.5 \mathrm{R}_{7}$ ). The predicted clay mineral abundances $(\mathrm{Vm}=5 \%, \mathrm{H}=45 \%$ and $\operatorname{Im}=30 \%$ ) may be related to the class 'Vermiculite + Halloysite' (Fig. 6), although V seems to be lower than expected and Im higher. Similarly, weathering under good drainage conditions produce '1:1 mixtures', but now of Al-rich allophane plus gibbsite (plagioclase: $0.5 \mathrm{R}_{3}+0.5 \mathrm{R}_{4}$ ) or vermiculite plus halloysite (pyroxene: $0.4 R_{6}+0.6 R_{7}$ ). As would be expected, mixtures derived from pyroxene are richer in halloysite when drainage is good $(60 \%$, in comparison to the $50 \%$ of the moderate drainage scenario). The predicted clay mineral abundances $(\mathrm{V}=5 \%, \mathrm{H}=5 \%, \mathrm{Im}=30 \%$ and $\mathrm{Gb}=40 \%)$, although low in $\mathrm{Vm}$ and $\mathrm{H}$, may grossly be attributed to the class 'Vermiculite + Allophane' (Fig. 6). The last drainage scenario produces mixtures of Al-rich allophane plus gibbsite (plagioclase: $0.1 R_{3}+0.9 R_{4}$, now $40 \%$ richer in gibbsite than in the previous scenario) or halloysite plus Al-rich allophane (pyroxene: $0.3 R_{7}+0.7 R_{8}$ ). In this case, the predicted clay mineral abundances $(\mathrm{H}=5 \%, \quad \mathrm{Im}=5 \%$ and $\mathrm{Gb}=70 \%$ ) suggest that weathering of Madeira basalts may proceed beyond the stage represented by the class 'Halloysite' (Fig. 6).

\subsection{Chemical weathering and denudation rates}

Mineral weathering rates were calculated by Eq. (3). The required concentrations of dissolved minerals and the recharge rates were set by the $\mathrm{SiB}$ algorithm and Eq. (2f). The results are shown in the last four columns of Table 4.

The average sequence of model-derived weathering rates is $\mathrm{Pl}>\mathrm{Ol}>\mathrm{Py}$ (Fig. 12d). In detail, this order applies to $52 \%$ of the cases, whereas in the remaining instances the sequences are $\mathrm{Pl}>\mathrm{Py}>\mathrm{Ol}$ (27\%), Ol $>\mathrm{Pl}>\mathrm{Py}(12 \%)$, and $\mathrm{Py}>\mathrm{Ol}>\mathrm{Pl}(9 \%)$. Olivine and pyroxene are both out of the commonly accepted sequence of $\mathrm{Ol}>\mathrm{Py}>\mathrm{Pl}$ (Goldich, 1938). Although the (Na,Ca)-feldspars are generally considered to be more resistant to weathering than pyroxene, the reversal in the sequence is not unique (Eggleton et al., 1987; Nesbitt and Wilson, 1992) and it has also been reported that the stabilities of these minerals are quite comparable (Colman, 1982). Our observations might be related to the fact that during weathering diffusion avenues in pyroxene crystals are frequently blocked by released iron oxides (Bland and Rolls, 1998). On the other hand, the rate of dissolution of a mineral depends on the departure from equilibrium or chemical affinity, $\Delta G_{\mathrm{r}}$ (Gíslason and Arnórsson, 1993; Drever, 1997). The saturation state of a mineral in contact with water depends on its composition. It has been shown that the saturation state of pyroxene decreases with increasing iron content and-though less pronounced-of plagioclase with decreasing $\mathrm{Ca}$ content (Gíslason and 
Table 4

Model results, listed in order of drainage conditions

\begin{tabular}{|c|c|c|c|c|c|c|c|c|c|c|c|c|c|c|c|}
\hline \multirow[t]{2}{*}{$\begin{array}{l}\text { Drainage } \\
\text { Conditions }\end{array}$} & \multirow[t]{2}{*}{ Complex } & \multirow[t]{2}{*}{$\mathrm{Nr}$} & \multirow[t]{2}{*}[\mathrm{Cl}]{$_{\mathrm{t}} /[\mathrm{Na}]_{\mathrm{u}}$} & \multirow[t]{2}{*}{$x$} & \multicolumn{2}{|c|}{$\begin{array}{l}\text { Weathering } \\
\text { reactions to Mixtures } \\
\text { of Clay Minerals }\end{array}$} & \multicolumn{5}{|c|}{$\begin{array}{l}\text { Predicted Clay Mineral } \\
\text { Abundances }\end{array}$} & \multirow[t]{2}{*}{$\begin{array}{l}\text { Recharge } \\
(\mathrm{mm})\end{array}$} & \multicolumn{3}{|c|}{$\begin{array}{l}\text { Weathering Rates } \\
\text { (mol/ha.y. } \\
\% \text { mineral) }\end{array}$} \\
\hline & & & & & $\mathrm{Pl}$ & Py & $\mathrm{Sm}$ & $\mathrm{Vm}$ & $\mathrm{H}$ & $\mathrm{Im}$ & $\mathrm{Gb}$ & & $\mathrm{Pl}$ & Py & $\mathrm{Ol}$ \\
\hline \multirow[t]{11}{*}{ Poor } & B1 & 101 & 1.00 & 0.40 & \multirow[t]{11}{*}{$\begin{array}{l}0.1 \mathrm{R}_{1 \mathrm{~b}} \\
+0.9 \mathrm{R}_{2}\end{array}$} & \multirow[t]{11}{*}{$\begin{array}{l}0.6 \mathrm{R}_{5 \mathrm{~b}} \\
+0.4 \mathrm{R}_{7}\end{array}$} & 10 & & 70 & & & 1464 & 58.5 & 40.2 & 45.6 \\
\hline & B1 & 103 & 1.05 & 0.40 & & & & & & & & 1447 & 57.9 & 37.7 & 47.4 \\
\hline & B1 & 104 & 0.93 & 0.40 & & & & & & & & 1388 & 65.3 & 63.8 & 70.3 \\
\hline & B1 & 105 & 1.22 & 0.40 & & & & & & & & 1391 & 67.8 & 45.2 & 67.5 \\
\hline & B1 & 107 & 1.03 & 0.45 & & & & & & & & 1462 & 78.3 & 48.1 & 59.7 \\
\hline & B1 & 126 & 1.17 & 0.60 & & & & & & & & 677 & 39.9 & 34.2 & 24.7 \\
\hline & B1 & 127 & 1.71 & 0.40 & & & & & & & & 1050 & 115.9 & 62.4 & 53.8 \\
\hline & B1 & 146 & 1.09 & 0.50 & & & & & & & & 1171 & 48.5 & 20.5 & 34.7 \\
\hline & B3 & 128 & 0.90 & 0.55 & & & & & & & & 983 & 70.3 & 5.2 & 33.7 \\
\hline & B3 & 130 & 1.07 & 0.55 & & & & & & & & 892 & 64.0 & 12.1 & 30.2 \\
\hline & B3 & 131 & 0.93 & 0.55 & & & & & & & & 1203 & 70.8 & 9.3 & 44.6 \\
\hline \multirow[t]{12}{*}{ Moderate } & B2 & 119 & 1.17 & 0.50 & \multirow[t]{12}{*}{$\begin{array}{l}0.6 R_{2} \\
+0.4 R_{3}\end{array}$} & \multirow[t]{12}{*}{$\begin{array}{l}0.5 \mathrm{R}_{6} \\
+0.5 \mathrm{R}_{7}\end{array}$} & & 5 & 45 & 30 & & 1466 & 36.6 & 23.2 & 16.7 \\
\hline & B3 & 114 & 1.10 & 0.55 & & & & & & & & 1428 & 46.6 & 21.8 & 15.9 \\
\hline & B3 & 115 & 1.13 & 0.55 & & & & & & & & 1483 & 44.9 & 37.7 & 37.9 \\
\hline & B3 & 117 & 1.01 & 0.55 & & & & & & & & 1506 & 37.8 & 35.6 & 40.3 \\
\hline & B3 & 118 & 1.03 & 0.55 & & & & & & & & 1451 & 49.8 & 25.5 & 42.8 \\
\hline & B3 & 123 & 1.17 & 0.55 & & & & & & & & 1072 & 45.6 & 35.0 & 36.6 \\
\hline & B3 & 124 & 1.04 & 0.55 & & & & & & & & 1131 & 44.1 & 37.8 & 39.0 \\
\hline & B3 & 125 & 0.95 & 0.55 & & & & & & & & 1212 & 44.7 & 46.7 & 46.6 \\
\hline & B3 & 129 & 0.92 & 0.55 & & & & & & & & 952 & 38.9 & 32.7 & 23.4 \\
\hline & B3 & 147 & 0.95 & 0.55 & & & & & & & & 788 & 30.6 & 18.3 & 29.4 \\
\hline & B3 & 148 & 1.07 & 0.55 & & & & & & & & 888 & 32.2 & 21.5 & 23.9 \\
\hline & B3 & 149 & 1.06 & 0.55 & & & & & & & & 883 & 33.3 & 21.1 & 23.2 \\
\hline \multirow[t]{7}{*}{ Good } & B2 & 113 & 1.17 & 0.50 & \multirow[t]{7}{*}{$\begin{array}{l}0.5 R_{3} \\
+0.5 R_{4}\end{array}$} & \multirow[t]{7}{*}{$\begin{array}{l}0.4 \mathrm{R}_{6} \\
+0.6 \mathrm{R}_{7}\end{array}$} & & 5 & 5 & 30 & 40 & 1289 & 15.4 & 22.2 & 20.5 \\
\hline & B2 & 134 & 1.17 & 0.45 & & & & & & & & 1419 & 39.4 & 20.3 & 29.4 \\
\hline & B2 & 135 & 1.17 & 0.50 & & & & & & & & 1087 & 44.3 & 23.0 & 20.2 \\
\hline & B2 & 140 & 1.17 & 0.50 & & & & & & & & 1069 & 49.3 & 17.6 & 17.2 \\
\hline & B3 & 132 & 1.08 & 0.55 & & & & & & & & 1393 & 11.1 & 13.1 & 19.0 \\
\hline & B3 & 138 & 1.17 & 0.55 & & & & & & & & 1468 & 35.0 & 22.0 & 16.5 \\
\hline & B3 & 143 & 1.17 & 0.60 & & & & & & & & 1466 & 19.3 & 16.7 & 21.9 \\
\hline \multirow[t]{3}{*}{ Very Good } & B2 & 136 & 1.17 & 0.50 & \multirow[t]{3}{*}{$\begin{array}{l}0.1 \mathrm{R}_{3} \\
+0.9 \mathrm{R}_{4}\end{array}$} & \multirow[t]{3}{*}{$\begin{array}{l}0.3 \mathrm{R}_{7} \\
+0.7 \mathrm{R}_{8}\end{array}$} & & & 5 & 5 & 70 & 1494 & 18.6 & 16.6 & 27.4 \\
\hline & B3 & 116 & 1.17 & 0.70 & & & & & & & & 1198 & 39.9 & 19.5 & 18.3 \\
\hline & B4 & 141 & 1.19 & 0.60 & & & & & & & & 1740 & 14.1 & 1.0 & 10.0 \\
\hline
\end{tabular}

\footnotetext{
The conceptual model of the relations between drainage conditions and the expected abundances of clay minerals in soils developed on the geological complexes (B1-B4) was presented in Fig. 10. The recharge rates were derived from a chloride-balance method (Eqs. (2a-i)). The coefficients of the best-fit sets of weathering reactions (Table 3) indicate the relative contributions of these reactions to the groundwater chemistries. The weathering rates were computed by combination of the contribution of each mineral to the groundwater composition and the recharge rate. $\mathrm{Nr}=$ number of spring, $\mathrm{x}=$ anorthite content of plagioclase, $[\mathrm{Cl}]_{\mathrm{t}}=$ chloride concentration in sporing water, $[\mathrm{Na}]_{\mathrm{u}}=$ residual sodium concentrations in spring water, $\mathrm{Pl}=$ plagioclase, $\mathrm{Py}=$ pyroxene, $\mathrm{Ol}=$ olivine, $\mathrm{Sm}=$ smectite, $\mathrm{Vm}=$ vermiculite, $\mathrm{H}=$ halloysite (in general kaolinite-group minerals), $\mathrm{Im}=$ imogolite (in general Al-rich allophane), $\mathrm{Gb}=$ gibbsite. The compositions assigned to these primary and secondary minerals were presented in Tables 1 and 2.
} 
Arnórsson, 1993; Stefánsson et al., 2001). These features may render the weatherability of Ca-rich plagioclase $>$ pyroxene (Berner and Berner, 1996). In cases where, as in Madeira basalts, olivine is abundant, released $\mathrm{Mg}^{2+}$ and $\mathrm{H}_{2} \mathrm{SiO}_{3}$ may also achieve sufficiently high levels in solution to stabilize other Mg-rich primary minerals such as pyroxene, whereas plagioclase may remain undersaturated and be dissolved (Nesbitt and Wilson, 1992).

With regard to olivine, it seems unlikely that its uncommon position in the weathering sequence is caused by clogging of solution channels in olivine, since its metastable alteration products do not fill the initial diffusion channels, allowing increasingly rapid diffusion as alteration increases (Eggleton and Smith, 1983). Rather, prolonged weathering of basaltic material might have depleted it in olivine relative to fresh basalt (Chesworth et al., 1981). Or else, an eventual episode of subsolidus oxidation of the basaltic lava enabled the laihunitization of olivine reducing its susceptibility to soil water attack (Banfield et al., 1990).

By all means, the Goldich sequence of weathering does not hold under all environmental conditions. It has been observed before that plagioclase and pyroxene weathered before adjacent olivine in basalts. The key of this reversal is the paucity of organic acids produced by lichen and the decay of vegetation (Wasklewicz, 1994). It has to be noted, however, that $\left.\left[\mathrm{Mg}^{2+}\right]^{*}\right] /\left[\mathrm{Ca}^{2+}\right]^{*}$ was probably higher during our summer campaign than in the other seasons, so the position of olivine in the weathering sequence may change accordingly. Also, dissolution of carbonate dust derived from dry deposition may upset the weathering sequences. We tested this hypothesis by repeating the calculations for all proposed scenarios, now including $\mathrm{CaCO}_{3}$ as one of the reactant phases. In all scenarios the number of spring compositions explained by the $\mathrm{SiB}$ algorithm was not more than $60 \%$. For the explained springs (considering the most reasonable fourth scenario) the median carbonate imports were found to be $45 \mathrm{~mol} /$ (ha y), which are consistent with the value proposed by Goudie and Middleton (2001) for the region (around $30 \mathrm{~mol} /$ (hay)). The sequences found in this case were $\mathrm{Pl}>\mathrm{Py}>\mathrm{Ol}(35 \%), \mathrm{Pl}>\mathrm{Ol}>\mathrm{Py}(30 \%), \mathrm{Ol}>$ $\mathrm{Pl}>\mathrm{Py}(30 \%)$ and $\mathrm{Py}>\mathrm{Pl}>\mathrm{Ol}(5 \%)$, meaning that the Goldich sequence is still not holding.
Weathering rates in Fig. 12d were normalised by volume percentages (Table 1). If in complexes B2B4 water tends to follow cracks and other fissures in the rock, they should instead have been normalised by a surface percentage. Should all minerals be sized equally and distributed in a manner that their abundances along three orthogonal directions are identical, and the relation between the surface percentage $\left(d_{\mathrm{A}}\right)$ and the volume percentage $\left(d_{\mathrm{V}}\right)$ would be given by

$d_{\mathrm{A}}=\left(\sqrt[3]{d_{\mathrm{V}}}\right)$

When normalised by $d_{\mathrm{A}}$, plagioclase rates increase by $12 \%$ whereas pyroxene and olivine rates decrease by $10-14 \%$ and $8-10 \%$, respectively. This means that in B2-B4 the dominance of plagioclase in the control of weathering is eventually more pronounced than was predicted before. It has to be added that $d_{\mathrm{A}}$ is just an approximation of the surface exposed to percolating solutions, and that surface roughness - the ratio between the BET surface area and the geometric surface area (used in Eq. (4)) —of the various minerals in contact with the solution also plays a role (White and Peterson, 1990a,b; Anbeek, 1992; Anbeek et al., 1994).

Apart from the detailed analysis of weathering rates of the various minerals, a rough estimate can be made of the average total chemical denudation rate. First the values of our median dissolved silica and cation (corrected for sea salt) concentrations are transformed into annual concentrations using the factors given in the Section 5 on hydrochemistry and then converted into corresponding oxides. Then, the sum of these oxide concentrations $(29.8 \pm 7.4 \mathrm{mg} / \mathrm{L})$ is multiplied with the median recharge $(1250 \pm 250 \mathrm{~mm} / \mathrm{y}$; cf. Table 4$)$, resulting in a chemical denudation rate of $37 \pm 12 \mathrm{~g}$ oxides/ $\left(\mathrm{m}^{2} \mathrm{y}\right) .{ }^{4}$ To calculate the ranges, we used the adopted $\pm 30 \%$ value of the ratio of annual to summer concentrations and $\pm 35 \%$ of the median values of concentrations and recharge. Combination of these

\footnotetext{
${ }^{4}$ It has to be realized that the results represent only shallow and not deep groundwater. The latter has longer residence times and consequently higher solute concentrations. Since part of the recharge will leave the studied area and emerge at lower altitudes or even below sea level, the calculated chemical denudation rates can be considered as minimum rates.
} 


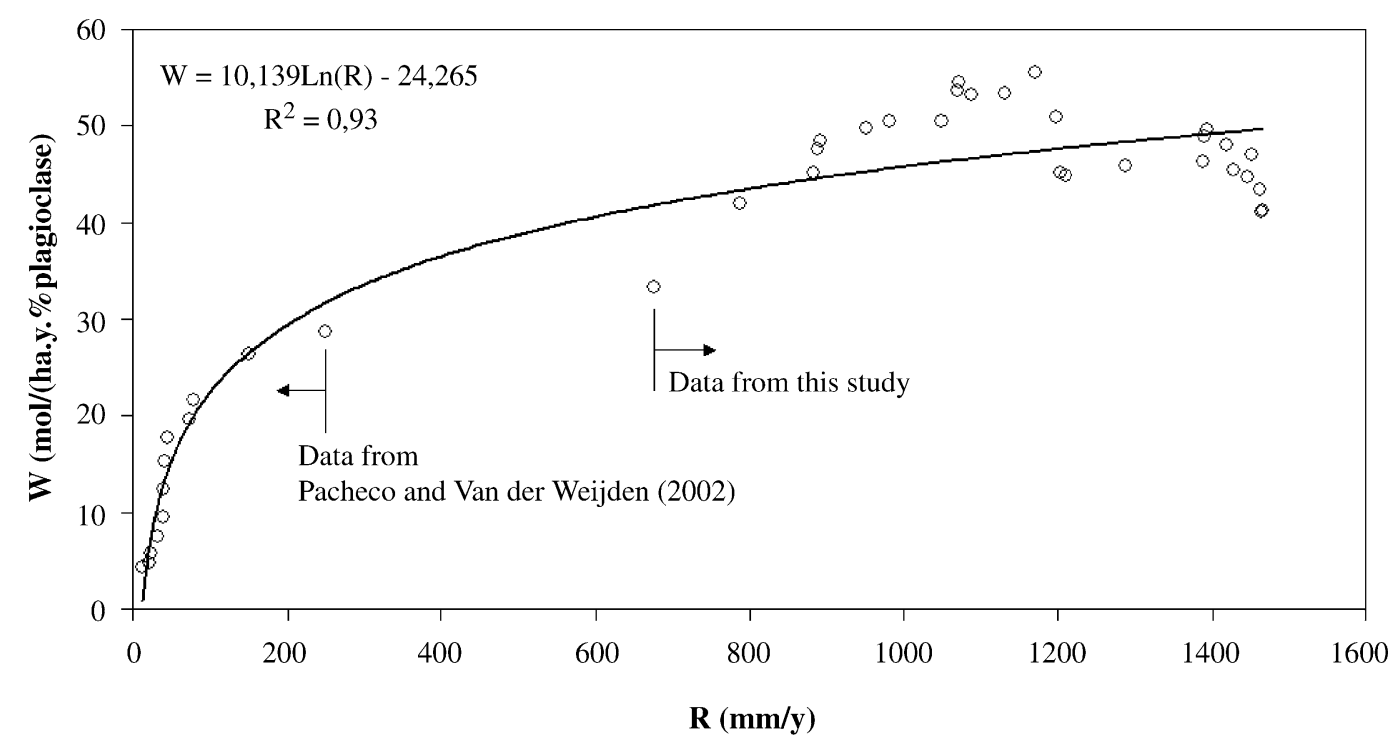

Fig. 13. Relation between weathering rates $(W)$ of plagioclase and recharge rates in catchments of springs $(R)$. The rates were smoothed by the moving average procedure prior to projection, normalized by the bulk percentages of the mineral, (in vol. \% as shown in Table 1).

errors in summations and multiplications was done in conventional statistical ways. We ignored structural water as well as minor dissolvable elements, which would have raised this amount a little, but this probably vanishes in the large uncertainty range. Anyway, the value is very similar to the average chemical erosion rate of $30 \mathrm{~g} /\left(\mathrm{m}^{2} \mathrm{y}\right)$ in volcanic rocks (Meybeck, 1987). The median bicarbonate concentration is $0.69 \pm 0.27 \mathrm{mmol} / \mathrm{l}$. In combination with the recharge rate, this means that the annual $\mathrm{CO}_{2}$ consumption in this area is $0.86 \pm 0.38 \mathrm{Mmol} / \mathrm{km}^{2}$, again a poorly constrained value but comparable with the results for Réunion Island $(0.94 \pm 0.17 \mathrm{Mmol} /$ $\mathrm{km}^{2}$; Louvat and Allègre, 1997), Iceland (1.1 Mmol/ $\mathrm{km}^{2}$; Gíslason et al., 1996) and Columbia River basalts (0.9 Mmol/ $\mathrm{km}^{2}$; Taylor and Lasaga, 1999).

\subsection{Relation with recharge rates}

In a study of the Morais Massif (northern Portugal), Pacheco and Van der Weijden (2002) noticed that weathering rates $(W)$ are mostly a function of the recharge rate $(R)$ and drew $W$ versus $R$ plots for plagioclase and amphibole. In their case, the relations between weathering rates and recharge rates were found to be linear, but their recharge rates were only in the interval $0-250 \mathrm{~mm}$. In this study, we show that for a much wider range of recharge rates (0-1700 mm, including the data compiled from Pacheco and Van der Weijden, 2002), the (W, R) scatter points fit to a logarithmic function that is asymptotic to $W=50 \mathrm{~mol} /$ (ha y \% plagioclase) (Fig. 13). It should be noted that our results are in agreement with theoretical investigations that suggest the following: (1) As the flushing rate is increased, the concentration of solutes decreases and the rate of dissolution increases; a point is reached at which the maximum rate of dissolution is independent of the flushing rate; (2) If flow is more sluggish, the concentration of solutes increases and the rate of dissolution decreases; ultimately, saturation is reached and the rate of dissolution is controlled only by the rate of flushing (Bland and Rolls, 1998).

\section{Conclusions}

Applying our SiB model, we succesfully achieved our main objective, namely relating the chemistry of groundwater to (combinations of) weathering reactions and rates of the three dominant primary minerals (olivine, pyroxene and plagioclase) into secondary minerals typical for andosols under prevailing drainage conditions in different volcanic units. We found 
Table A1

Listed under the heading "Location" are the topographical positions, altitudes, geological complexes (B's) and positions north or south of the divide (Fig. 1) where water samples

were collected. Compositions of the water samples and checks on the ion balance are given in columns 7-16. Field measurements of pH, $E C$ and $T$ are listed in the last three

columns. Missing values are indicated by question marks

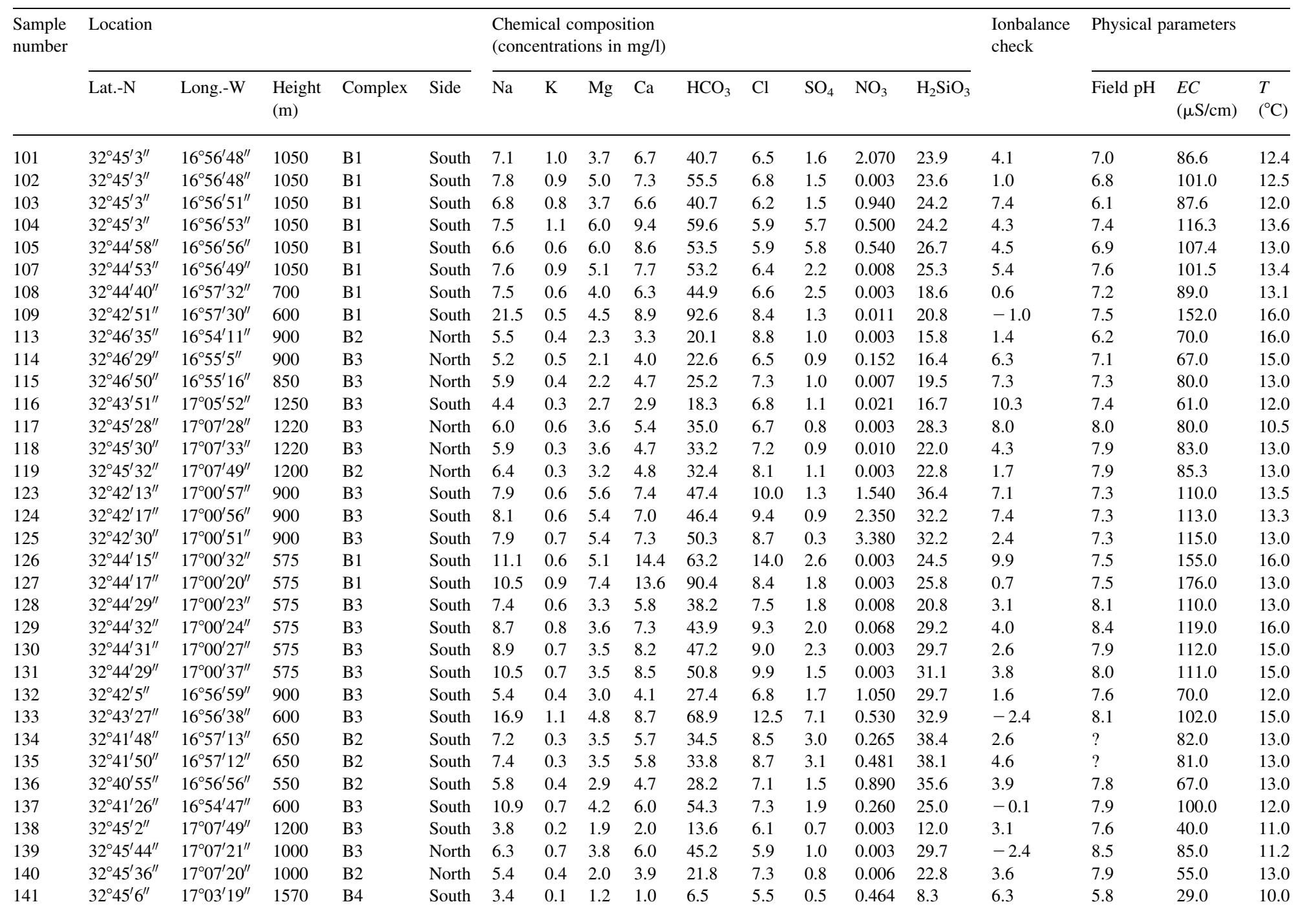


that in $52 \%$ of the cases the weathering rate of plagioclase exceeds the rates of olivine and pyroxene; in $94 \%$ of the cases within this group the weathering rate of olivine is greater than of pyroxene. The average weathering rates (as moles/(ha y \% mineral)) are: $44 \pm 19$ (plagioclase), $29 \pm 14$ (pyroxene) and $22 \pm 13$. For the case of plagioclase it is shown that the weathering rate reaches an asymptotic value of about $50 \mathrm{~mol} /$ (ha y \%mineral) at recharge rates $\approx$ $1600 \mathrm{~mm} / \mathrm{y}$. A rough estimate of the total chemical weathering rate in the studied area is $37 \pm 12 \mathrm{~g} /\left(\mathrm{m}^{2} \mathrm{y}\right)$, consuming $0.86 \pm 0.38 \mathrm{~mol} \mathrm{CO}_{2} / \mathrm{m}^{2}$.

\section{Acknowledgements}

Gonneke Cornelisse, Harald Dik and Anne Jongkind carried out fieldwork and wrote a student report on the water chemistry of the island. Chemical analyses were performed by Helen de Waard (ICPAES) and Ronald van Miltenburg (IC). Dr Domingos Rodrigues (University of Madeira, Funchal) introduced us to the geology and pedology of Madeira, and the director of the Instituto de Gestão da Agua (Funchal) helped us in getting additional information about the hydrochemistry on the island. Special thanks are owed to Susana Nascimento Prada for sharing her thesis results with us. We thank Dr J.P. Gustav Loch and two anonymous reviewers for their thorough evaluations and constructive comments on the previous draft of the paper.

\section{Appendix}

see Table A1

\section{References}

Almeida, C., Romariz, C., Silva, M.O., 1984. Hydrochemistry of Madeira island. Revista Recursos Hídricos 5, 33-42.

Anbeek, C., 1992. Surface roughness of minerals and implications for dissolution studies. Geochimica et Cosmochimica Acta 56, $1461-1470$.

Anbeek, C., Van Breemen, N., Meijer, E.L., Van der Plas, L., 1994. The dissolution of naturally weathered feldspar and quartz. Geochimica Cosmochimica Acta 58, 4601-4613. 
Banfield, J.F., Veblen, D.R., Jones, B.F., 1990. Transmission electron microscopy of subsolidus oxidation and weathering of olivine. Contributions to Mineralogy and Petrology 106, $110-123$.

Bates, T.S., Cline, J.D., 1985. The role of the ocean in a regional sulfur cycle. Journal of Geophysical Research 90, 9168-9172.

Benson, L.V., Teague, L.S., 1982. Diagenesis of basalts from the Pasco Basin, Washington-I. Distribution and composition of secondary mineral phases. Journal of Sedimentary Petrology 52, 595-613.

Berner, R.A., Berner, E.K., 1996. Global Environment: Water, Air, and Geochemical Cycles, Prentice Hal, Upper Saddle River, NJ, $151 \mathrm{pp}$.

Berner, R.A., Cochran, M.F., 1998. Plant-induced weathering of Hawaiian basalts. Journal of Sedimentary Research 68, $723-726$.

Bland, W., Rolls, D., 1998. Weathering: An Introduction to the Scientific Principles, Arnold, London, 271pp.

Bowser, C.J., Jones, B.F., 2002. Mineralogic controls on the composition of natural waters dominated by silicate hydrolysis. American Journal of Science 302, 582-662.

Chesworth, W., Dejou, J., Larroque, P., 1981. The weathering of basalt and relative mobilities of the major elements at Belbex, France. Geochimica Cosmochimica Acta 45, 1235-1243.

Colman, S.M., 1982. Chemical Weathering of Basalts and Andesites: Evidence from Weathering Rinds, Geological Survey Professional Paper 1246, US Government Printing Office, Washington, 51pp.

Craig, D.C., Loughnan, F.C., 1964. Chemical and mineralogical transformations accompanying the weathering of basic volcanic rocks from New South Wales. Australian Journal of Soil Research 2, 218-234.

Custodio, E., Llamas, M.R., 1976. Hidrologia Subterránea. Editiones Omega, Barcelona, 2359 pp.

Deer, W.A., Howie, R.A., Zussmann, J., 1974. An introduction to the Rock Forming Minerals, Longman Group Ltd, London, 528pp.

Dahlgren, R., Shoji, S., Nanzyo, M., 1993. In: Shoji, S., Nanzyo, M., Dahlgren, R.A. (Eds.), Volcanic Ash Soils. Genesis, Properties and Utilization, Developments in Soil Science, vol. 21. Elsevier, Amsterdam, pp. 101-143.

Drever, J.I., 1997. Weathering processes. In: Saether, O.M., De Caritat, P. (Eds.), Geochemical Processes, Weathering and Groundwater Recharge in Catchments, A.A. Balkema, Rotterdam, pp. 3-19.

Drever, J.L., Clow, D.W., 1995. Weathering rates in catchments. In: White, A.F., Brantley, S.L. (Eds.), Chemical Weathering rates of Silicate Minerals, Reviews in Mineralogy, vol. 31. Mineralogical Society of America, Washington, DC, pp. 463-483.

Eggleton, R.A., Smith, K.L., 1983. Silicate alteration mechanisms. Sciences Géologiques Mémoires 71, 45-53.

Eggleton, R.A., Foudoulis, C., Varkevisser, D., 1987. Weathering of basalt: changes in rock chemistry and mineralogy. Clays and Clay Minerals 35, 161-169.

Ferreira, J.P.C.L., Rodrigues, J.D., 1987. BALSEQ—a model for the estimation of water balances, including aquifer recharge, requiring scarce hydrogeological data. In: Simmers, I., (Ed.), Estimation of Natural Groundwater Recharge, Proceedings of ARW, Antalya (Turkey), 510pp.

Furtado, A.F.A.S., 1983. As argilas dos solos da ilha da Madeira. Alguns aspectos relacionados com a sua génese. Anais do Instituto Superior de Agronomia/Lisboa XLI, $131-152$.

Furtado, A., Madeira, M., Jeanroy, E., 1990. Mineralogy of soils from Madeira island (Portugal). Solubility of the iron oxides. Sciences Géologiques Bulletin 43, 139-149.

Garrels, R.M., 1967. Genesis of some ground waters from igneous rocks. In: Abelson, P.H., (Ed.), Researches in Geochemistry, vol. 2. Wiley, New York, pp. 405-420.

Garrels, R.M., Mackenzie, F.T., 1967. Origin of the chemical compositions of some springs and lakes. In: Stumm, W., (Ed.), Equilibrium Concepts in Natural Water Systems, Advances in Chemistry Series 67, American Chemical Society, Washington, pp. 222-242.

Gíslason, S.R., Eugster, H.P., 1987. Meteoric water-basalt interactions. II: A field stdy in N.E. Iceland. Geochimica Cosmochimica Acta 51, 2841-2855.

Gíslason, S.R., Arnórsson, S., 1993. Dissolution of primary basaltic minerals in natural waters: saturation state and kinetics. Chemical Geology 105, 117-135.

Gíslason, S.R., Arnórsson, S., Armannson, H., 1994. Present chemical weathering of basalt in Iceland. Mineralogical Magazine 58A, 333-334.

Gíslason, S.R., Arnórsson, S., Armannson, H., 1996. Chemical weathering of basalt in southwest Iceland: Effects of runoff, age of rocks and vegetative glacial cover. American Journal of Science 296, 837-907.

Goldich, S.S., 1938. A study in rock weathering. Journal of Geology 46, 17-58

Goudie, A.S., Middleton, N.J., 2001. Saharan dust storms: nature and consequences. Earth-Science Reviews 56, 179-204.

Hermann, L., Jahn, R., Stahr, K., 1996. Identification and quantification of dust additions in peri-Saharan soils. In: Guerzoni, S., Chester, R. (Eds.), The Impact of Desert Dust Across the Mediterranean, Kluwer, Netherlands, pp. 173-182.

Langmuir, D.m., 1997. Aqueous Environmental Geochemistry, Prentice-Hall, Upper Saddle River, NJ, 600pp.

Li, Y-H., 1988. Denudation rates of the Hawaiian islands by rivers and groundwaters. Pacific Science 423, 253-266.

Loughnan, F.C., 1969. Chemical Weathering of the Silicate Minerals, American Elsevier Publishing Company, New York, 155pp.

Loureiro, J.J.M., 1984. Monografia hidrológica da ilha da Madeira. Revista Recursos Hídricos. Associação Portuguesa dos Recursos Hídrocos (APHR)/Lisboa 5, 53-71.

Louvat, P., Allègre, C.J., 1997. Present denudation rates on the island of Réunion determined by river geochemistry: Basalt weathering and mass budget between chemical and mechanical erosion. Geochimica Cosmochimica Acta 61, 3645-3669.

Luria, M., Van Valkin, C.C., Galloway, J.N., Keene, W.C., Wellman, D.L., Sievering, H., Boatman, J.F., 1989. The relationship between dimethyl sulfide and particulate 
sulfate in the Mid-Atlantic atmosphere. Atmospheric Environment 23, 139-147.

Madeira, M., Furtado, A., Jeanroy, E., Herbillon, A.J., 1994. Andisols of Madeira Island (Portugal). Characteristics and classification. Geoderma 62, 363-383.

Mata, J.M.L.S., 1996. Petrologia e Geoquímica das Lavas da Ilha da Madeira: Implicações para os Modelos de Evolução do Mato Terrestre. PhD Thesis, Lisboa University, 471pp.

McBride, M.B., 1994. Environmental Chemistry of Soils, Oxford University Press, New York, 406pp.

Meybeck, M., 1987. Global chemical weathering of surficial rocks estimated by river dissolved loads. American Journal of Science 70, 401-428.

Nanzyo, M., Dahlgren, R., Shoji, S., 1993. Chemical characteristics of volcanic ash soils. In: Shoji, S., Nanzyo, M., Dahlgren, R.A. (Eds.), Volcanic Ash Soils. Genesis, Properties and Utilization, Developments in Soil Science, vol. 21. Elsevier, Amsterdam, pp. $145-187$.

Nascimento, S.L.R., 1990. Estudo Hidrogeológico do Paúl da Serra. MSc Thesis, Lisboa University. 148pp.

Nesbitt, H.W., Wilson, R.E., 1992. Recent chemical weathering of basalts. American Journal of Science 292, 740-777.

Noack, Y., Matthieu, D., Claparols, C., Loubet, M., Bernat, M., Goncalves, N., 1990. Weathering of basalts in North Parana Basin (Brazil): Chemical Aspects. Chemical Geology 84, $111-115$.

Novo, M.E.J.S., Leitão, T.E., Tore, C.S., Ferreira, J.P.C.L., 1994. Avaliação dos Recursos Hídricos Subterrâneos da Ilha da Madeira. Laboratório Nacional da Engenharia Civil (LNEC), Departamento de Hidráulica, Grupo de Investigação de Àguas Subterrâneas, Proc. 607/1/10087, 159pp.

Pacheco, F.A.L., Van der Weijden, C.H., 1996. Contributions of water-rock interactions to the composition of groundwater in areas with sizeable anthropogenic input. A case study of the waters of the Fundão area, central Portugal. Water Resources Research 32, 3553-3570.

Pacheco, F.A.L., Van der Weijden, C.H., 2002. Mineral weathering rates calculated from spring water data. A case study in an area with intensive agriculture, the Morais massif, NE Portugal. Applied Geochemistry 17, 583-603.

Pacheco, F.A.L., Oliveira, S.A., Van der Weijden, A.J., Van der Weijden, C.H., 1999. Weathering, biomass production and groundwater chemistry in an area of dominant anthropogenic influence, the Chaves-Vila Pouca de Aguiar region, north of Portugal. Water, Air and Soil Pollution 115, 481-512.

Prada, S.N., 2000. Geologia e Recursos Hídricos Subterrâneos da Ilha da Madeira. PhD thesis. Universidada da Madeira.

Prada, S.N., Silva, M.O., 2001. Fog precipitation on the Island of Madeira (Portugal). Environmental Geology 41, 384-389.

Ricardo, R.P., Câmara E.M.S., Ferreira, M.A.M., 1992. Carta dos Solos da Ilha da Madeira. Secretaria Regional de Economia, Direcção Regional de Agricultura, Lisboa. 162pp.

Rodrigues, F.F., Pio, C.A., Fialho, P.S., Lobo, A., Carvalho, A., Cerqueira, M.A., 2001. Chemical characterisation of marine aerosol in the Azores. Physics and Chemistry of the Earth (B) 26, $831-834$.

Rollinson, H., 1993. Using Geochemical Data: evalution, presentation, interpretation, Longman Scientific and Technical, Harlow, England, 352pp.

Schwertmann, U., Taylor, R.M., 1977. Iron oxides. In: Dixon, J.B., Weed, S.B., Kittrick, J.A., Milford, M.H., White, J.L. (Eds.), Minerals in Soil Environments, Soil Science Society of America, Madison, Wisconsin, USA, pp. 145-180.

Silva, M.O., 1988. Hidrogeológia da ilha da Madeira. Geolis II (1), 95-102.

Smith, K.I., Milnes, A.R., Eggleton, R.A., 1987. Weathering of basalt: formation of iddsingite. Clays and Clay Minerals 35, 418-428.

Sparks, D.L., 1995. Environmental Soil Chemistry, Academic Press, San Diego, 267pp.

Stefánsson, A., Gíslason, S.R., 2001. Chemical weathering of basalts, southwest Iceland: Effect of rock crystallinity and secondary minerals on chemical fluxes to the ocean. American Journal of Science 301, 513-556.

Stefánsson, A., Gíslason, S.R., Arnórsson, S., 2001. Dissolution of primary minerals in natural waters. II. Mineral saturation state. Chemical Geology 172, 251-276.

Sverdrup, H.U., 1990. The kinetics of base cation release due to chemical weathering, Lund University Press, 246pp.

Taylor, A.B., Velbel, M.A., 1991. Geochemical mass balances and weathering rates in forested watersheds of the southern Blue Ridge II. Effects of botanical uptake terms. Geoderma 51, 29-50.

Taylor, A.S., Lasaga, A.C., 1999. The role of basalt weathering in the $\mathrm{Sr}$ isotope budget of the oceans. Chemical Geology 161, 199-214.

Velbel, M.A., 1993. Constancy of silicate-mineral weathering-rate ratios between natural and experimental weathering: implications for hydrologic control of differences in absolute rates. Chemical Geology 105, 89-99.

Wada, K., 1985. The distinctive properties of andosols. In: Stewart, B.A., (Ed.), Advances in Soil Science, vol. 2. Springer, New York, pp. 173-229.

Wasklewicz, T.A., 1994. Importance of environment on the order of mineral weathering in olivine basalts, Hawaii. Earth Surface Processes and Landforms 19, 715-734.

White, A.F., Peterson, M., 1990a. The role of reactive surface areas in chemical weathering. Chemical Geology 84, 334-336.

White, A.F., Peterson, M., 1990b. Role of reactive-surface-area characterization in geochemical kinetic models. In: Melchior, D.C., Bassett, R.L. (Eds.), Chemical Modelling of Aquous Systems II, ACS Symposium Series 416, American Chemical Soceity, Washington, pp. 459-475.

Zbyszewski, G., Ferreira., O.V., Medeiros, A.C., Aires Barros L., Silva, L.C., Munhá, J., Barriga, F., 1975. Notícia Explicativa das Folhas A e B da Ilha da Madeira. Carta Geológica de Portugal na escala 1/50000. Serviços Geológicos de Portugal. 53pp. 